\title{
Evolution and estimated age of the C5 Lukala carbonate-evaporite ramp complex in the Lower Congo region (Democratic Republic of Congo): New perspectives in Central Africa
}

\author{
F. Delpomdor ${ }^{a,{ }^{*}}$, N. Van Vliet ${ }^{b}$, X. Devleeschouwer ${ }^{c}$, L. Tack $^{\mathrm{d}}$, A. Préat ${ }^{\mathrm{b}}$ \\ a Illinois State Geological Survey, University of Illinois, Champaign, IL 61820, United States \\ ${ }^{\mathrm{b}}$ Biogeochemistry and Modeling of the Earth System, Université libre de Bruxelles, Brussels, 1050, Belgium \\ ${ }^{\mathrm{c}}$ Royal Belgian Institute of Natural Sciences, Geological Survey of Belgium, Brussels 1000, Belgium \\ ${ }^{\mathrm{d}}$ Royal Museum for Central Africa, Tervuren, 3080, Belgium
}

\section{A R T I C L E I N F O}

\section{Article history:}

Received 14 April 2017

Received in revised form

23 October 2017

Accepted 24 October 2017

Available online 27 October 2017

\section{Keywords:}

Ediacaran

West Congo supergroup

Carbonates

Facies analysis

Carbon

Oxygen and strontium isotopes

Geochemistry

\begin{abstract}
A B S T R A C T
New detailed lithological, sedimentological, chemostratigraphic data were obtained from exploration drilling samples on the C5 carbonate-dominated formation of the Neoproterozoic Lukala Subgroup (former Schisto-Calcaire Subgroup) from the West Congo Belt (WCB) in the Democratic Republic of Congo. This formation records the last post-Marinoan sea-level events that occurred in the whole basin, followed by the development of the Araçuaï-West Congo Orogen between 630 and 560 Ma. The C5 Formation consists of back-reef lagoonal and peritidal/sabkha cycles of $\sim 2.0 \mathrm{~m}$ in thickness, that record a short-time marine regression, rapidly flooded by a marine transgression with deposition of organic-rich argillaceous carbonates or shales under dysoxia and anoxia conditions. These dysoxic/anoxic waters were rapidly followed by a regional-scale marine transgression, favouring mixing with well-oxygenated waters, and the development of benthic Tonian to Cambro-Ordovician Obruchevella parva-type 'seagrasses' in the nearshore zones of the lagoons. New $\delta^{13} \mathrm{C}$ and ${ }^{87} \mathrm{Sr} /{ }^{86} \mathrm{Sr}$ isotopic data in the C5 Formation of the Lukala Subgroup are used in the frame of a correlation with the Sete Lagoas Formation in Brazil. Relatively comparable negative to positive $\delta^{13} \mathrm{C}$ excursions point to marine flooding of the whole basin and allow extension of the debatable Late Ediacaran age of the uppermost Sete Lagoas and $\mathrm{C} 5$ formations. $\mathrm{Sr}$ isotope "blind dating" failed due to low $\mathrm{Sr}$ concentration related to a dolomitization event close 540 Ma. Several tentative datings of the C5 Formation converge to a Late Ediacaran age ranging between 575 and $540 \mathrm{Ma}$. As the overlying Mpioka folded Subgroup, the C5 series suffered the Pan African deformation, dated at $566 \pm 42 \mathrm{Ma}$. Unlike the previously generally accepted interpretation, our data suggests that the Mpioka Subgroup was deposited in the Early Cambrian.
\end{abstract}

(c) 2017 Elsevier Ltd. All rights reserved.

\section{Introduction}

The purpose of this paper is to focus on the carbonate-evaporite ramp evolution of the C5 Formation of the Lukala Subgroup (former Schisto-Calcaire Subgroup) from the West Congo Belt (WCB) in the Democratic Republic of Congo (DRC) (Frimmel et al., 2006). This formation contains dolomitized oolitic grainstones, lime mudstones and shales that were interpreted as post-Marinoan lagoonal and coastal deposits (Alvarez, 1995). Our principal objective is to reevaluate competing interpretations of this post-Marinoan marine

\footnotetext{
* Corresponding author.

E-mail address: fdelpomd@illinois.edu (F. Delpomdor).
}

transgressive succession, from $\mathrm{C} 5 \mathrm{a}$ to upper $\mathrm{C} 5 \mathrm{~b}$ members. The Snowball Earth hypothesis postulates an equatorial palaeolatitude location of this Neoproterozoic glacial succession, which was followed by a sudden return to a greenhouse mode with marine transgression, due to the increase of the atmospheric carbon dioxide from volcanic degassing that caused the deglaciation (Kirschvink, 1992; Hoffman and Schrag, 2002). This hypothesis has triggered numerous studies on the stratigraphic evolution in the Cryogenian and Ediacaran periods (Derry et al., 1994; Halverson et al., 2005, 2007, 2010; Kaufman et al., 2010). However, recent studies of the WCB have revealed only a minor impact of these glaciations on sedimentation. On the contrary, predominantly extensional tectonic activity controlled basin formation with 
dolostones (at the base of the Lukala Subgroup) abruptly overlying the Upper Diamictite Formation, formerly considered as a glaciogenic deposit (Eyles and Januszcak, 2007; Delpomdor et al., 2014, 2016, 2017). In this paper, new detailed lithofacies associations, stratigraphic architecture and geochemistry of the C5 Formation point to a paleogeographic setting with a vast shallow back-reef lagoon stretching between a stromatolitic patch reef and a coastal sabkha plain. These paleoenvironments experienced warm and dry to semi-arid climates, and were seasonally flooded by meteoric waters.

Our $\delta^{13} \mathrm{C}$ and ${ }^{87} \mathrm{Sr} /{ }^{86} \mathrm{Sr}$ are compared with the reference isotopic curves used for the current Cryogenian-Ediacaran stratigraphic subdivisions (Halverson et al., 2005; Jacobsen and Kaufman, 1999; Kaufman et al., 2010) and led to a deposition time of the C5 Formation between 575 and $550 \mathrm{Ma}$, in agreement with the previous radiometric and chemostratigraphic data (Frimmel et al., 2006; Poidevin, 2007; Cailteux et al., 2015). Moreover, due to the occurrence of the index fossil Obruchevella parva, we argue that the C5 carbonate-evaporite ramp succession was deposited after $580 \mathrm{Ma}$. Around $540 \mathrm{Ma}$, the C5 Formation has been altered by dolomitization. Finally, we discuss the implications of our results with respect to the presumed depositional age of the Pan African molasses (Mpioka Subgroup) of the WCB, traditionally ascribed to be older than $566 \pm 42 \mathrm{Ma}$.

\section{Regional setting}

The research area encompasses some $1400 \mathrm{~km}$ of exposures along the western margin of the Congo Craton extending from southwestern Gabon, across the Republic of Congo to the western part of the DRC and to northern Angola (Fig. 1). The Pan-African WCB is part of the Araçuaí-West Congo Orogen (AWCO) formed during Gondwanaland amalgamation ( 550 Ma) (Pedrosa-Soares et al., 2008; Pedrosa-Soares and Alkmin, 2011). It is subdivided into aulacogen foreland and thrust-and-fold belt domains that differ in deformation style and metamorphic grades (Tack et al., 2001, 2016). The foreland domain is composed of subtabular unmetamorphosed rocks and reaches its maximum thickness at around $5^{\circ} \mathrm{S}$ in the Lower Congo region. Correspondingly, it is the reference area for descriptions of the sedimentary strata of the belt (see Frimmel et al., 2006). To the west, in contrast, strata of the thrust-and-fold belt domain are metamorphosed (Frimmel et al., 2006). In the DRC, the lithostratigraphic terminology of the West Congo Supergroup (WCS) has been recently redefined. It is subdivided, from oldest to youngest, into the sedimentary and/or magmatic 1000-930 Ma Matadi, the 920-910 Ma Tshela/Seke Banza (including the Inga/Lufu- and Gangila-type bimodal magmatism), and the predominantly sedimentary $\sim 910-560$ Ma Cataractes groups (Baudet et al., 2014) (Fig. 2). Correlation of the new and previous terminology (respectively Zadinian, Mayumbian and West Congolian groups) falls out of the scope of this paper but is briefly discussed in Kant-Kabalu et al. (2016). The rocks collectively record a long-lived initial rift setting followed by a passive margin episode with carbonate platform deposits. The Cataractes Group (CG) is informally subdivided into the Sansikwa, Haut-Shiloango, Lukala and Mpioka subgroups (Kant-Kabalu et al., 2016) (Fig. 2). Two diamictite units, i.e., the Lower Diamictite Formation (LDF) and the Upper Diamictite Formation (UDF) form the upper parts of respectively the Sansikwa and Haut-Shiloango subgroups. Recently, the LDF was re-interpreted as sediment gravity mass deposits (Muanza-Kant et al., 2016). For the UDF of the WCB, recent sedimentological observations indicate sediment gravity flows with possible but only limited glaciogenic influence (Tack et al., 2006; Delpomdor et al., 2016, 2017).

The Lukala Subgroup (ca. $1100 \mathrm{~m}$-thick) is considered as a post-
Marinoan carbonate-rich succession, deposited on a carbonate ramp with a deep-marine outer ramp, a mid-ramp setting and a very shallow-marine inner ramp. The sedimentary record indicates oolitic shoal barriers, stromatolitic bioherms, lagoon and sabkhatype environments (Cahen, 1954, 1978; Alvarez, 1995; Préat et al., 2010, 2011; Cailteux et al., 2015; Delpomdor et al., 2015a, 2016). Initially, the Subgroup was subdivided into four units, the Kwilu, Lukunga, Bangu and Ngandu (Delhaye and Sluys, 1923; Cahen, 1954; Lepersonne, 1974; Cahen and Lepersonne, 1976), and later into five formations (C1 to C5) (Delhaye and Sluys, 1920, 1924a, 1924b, 1929; Lepersonne, 1974). In this study, only the C5 Formation is considered. A detailed description of the entire Lukala Subgroup was recently published by Cailteux et al. (2015). The C5 Formation is subdivided into three members, the $\mathrm{C5a}, \mathrm{C} 5 \mathrm{~b}$ and upper $\mathrm{C} 5 \mathrm{~b}$ members including the upper $\mathrm{C} 5 \mathrm{~b} 1$ and upper $\mathrm{C} 5 \mathrm{~b} 2$ submembers (Lepersonne, 1974). It is characterized by a variably dolomitic and/or organic-rich carbonate succession, with oolite, chert and shale beds. The C5 Formation is marked by (i) $20-40 \mathrm{~m}$ thick of dark lenticular calcareous conglomerates or breccias with oolitic beds overlain by dark dolomitic limestones with cherts ( $\mathrm{C} 5 \mathrm{a}$ Member), (ii) 10-40 m-thick Kisantu Oolite unit in the lower part of the C5b Member with lenticular beds of silicified oolites or pseudooolites - containing filamentous cyanobacterium Obruchevella parva in their nucleus (see Alvarez et al., 1995) - interbedded with shales and massive lime mudstones, this unit is overlain by massive to laminar dolomitic limestones, and (iii) 95-135 m-thick of dark crystalline dolomitic limestones and dolostones, often cherty and talceous, interbedded with shales and calcpelites (upper C5b1 submember), and (iv) 30-50 m-thick pale-greyish to whitish dolomitic limestones including cm-thick beds of silicified oolites, locally with talc (upper C5b2 submember; Lepersonne, 1974).

\section{Geochronology}

The absolute age of the WCB is relatively well constrained (Fig. 2). The Sansikwa Subgroup is younger than 920-910 Ma (Tack et al., 2001). Basalts with tholeiitic affinity - including the Kimbungu pillows and hyaloclastic breccias - are interlayered in the UDF whereas the Sansikwa Subgroup is intruded by the Sumbi-type dolerite feeder sills and dykes (De Paepe et al., 1975; Kampunzu et al., 1991). U-Pb determinations on baddeleyite single-grains from a dolerite sill yielded a crystallization age of $694 \pm 4 \mathrm{Ma}$ (Straathof, 2011), a younger age than the formerly accepted Sturtian age. In Gabon, zircons from a tuff in the metasedimentary Louila Formation yielded a U-Pb SHRIMP age of $\leq 713 \pm 49$ Ma (Thiéblemont et al., 2009). The Louila Formation is a stratigraphic equivalent to the Sansiskwa Subgroup in DRC (Delpomdor and Préat, 2015). Detrital zircon geochronology and provenance analysis of the LDF gave a maximum depositional age of $\sim 700 \mathrm{Ma}$ (Muanza-Kant et al., 2016). These ages on the LDF constrain episodic extensional activity recorded on the present-day African side of the AWCO (loosely dated 735-675 Ma "E6" rifting event; Pedrosa-Soares and Alkmin, 2011). Detrital U-Pb single-zircon dating of the bottom contact of the upper formation of the HautShiloango Subgroup points to a maximum depositional age of $\sim 650 \mathrm{Ma}$ (Frimmel et al., 2006). Carbonates of the uppermost Haut Shiloango were probably deposited around $645 \mathrm{Ma}$, according to near-primary ${ }^{87} \mathrm{Sr} /{ }^{86} \mathrm{Sr}$ ratios which are similar to carbonates deposited during this time interval worldwide (Frimmel et al., 2006; Poidevin, 2007). Similarly, carbonates of the SchistoCalcaire Subgroup (C4) - overlying the UDF - were deposited around $\sim 575 \mathrm{Ma}$ (Poidevin, 2007). Other recent attempts to constrain the depositional age of the Haut-Shiloango (or the stratigraphically equivalent Louila and/or Bouenza formations from the Republic of Congo), Lukala and Mpioka subgroups or of the UDF 


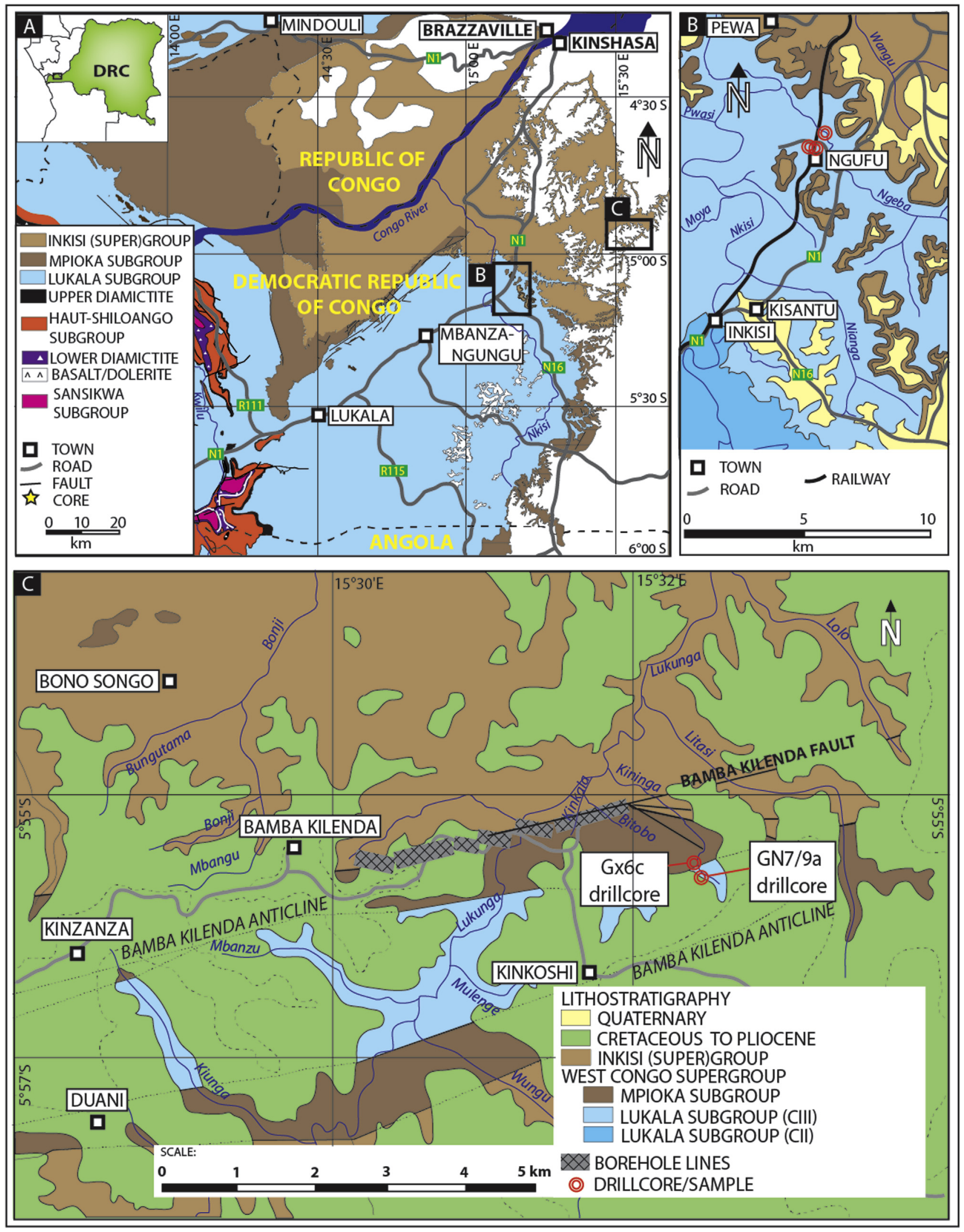

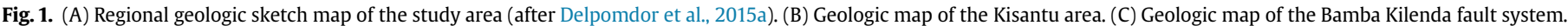

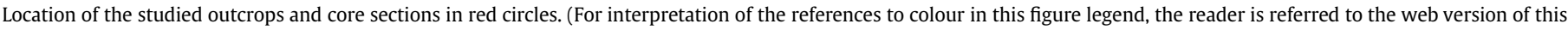
article.) 


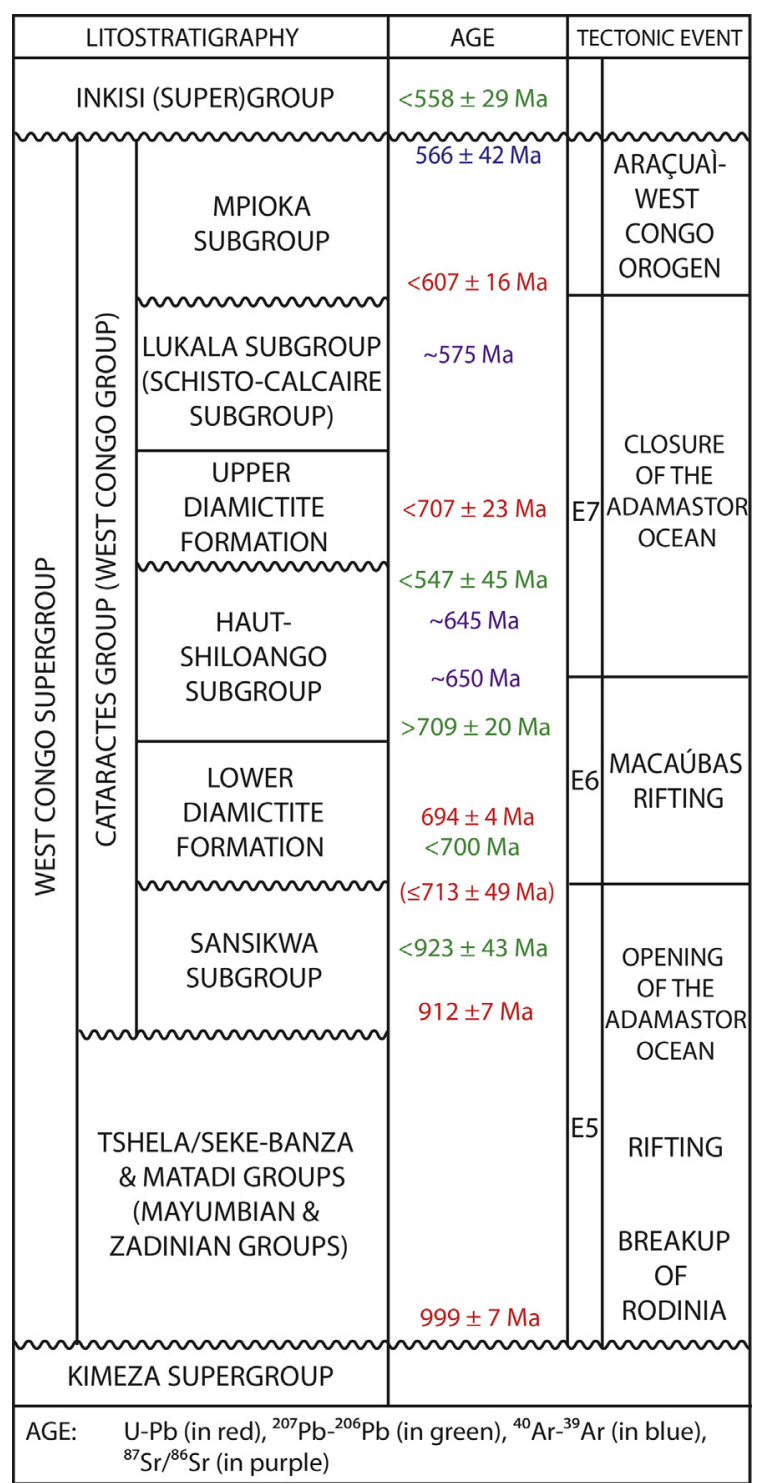

Fig. 2. Lithostratigraphy, geochronology, and tectonic events of the West Congo Supergroup in Lower Congo (see text for age). Modified after Tack et al. (2001).

proved to be unsuccessful in so far that they are unprecise (Affaton et al., 2016), or that the obtained maximum ages of deposition are too old in view of available regional geology data (Straathof, 2011). Regional metamorphism of the WCB is constrained by an Ar-Ar age of $566 \pm 42 \mathrm{Ma}$ (Fig. 2; Frimmel et al., 2006), in good agreement with the $\sim 585-560$ Ma orogenic climax of the AWCO in Brazil (Pedrosa-Soares et al., 2011).

\section{Materials and methods}

The study areas lie at Ngufu and along the Bamba Kilenda anticline, situated about $100 \mathrm{~km}$ south-west of Kinshasa in the Lower Congo Province (DRC) (Fig. 1A). The studied section crops out in a well-preserved quarry and in two poorly exposed cliffs (Fig. 1B) along the Ngeba river. In addition, access was granted to two drillcores, GN7/9a and Gx6c (Bamba Kilenda region; Fig. 1C), stored at the Geological Department of the Royal Museum for Central Africa (RMCA) in Tervuren, Belgium. A total of 277 samples were collected following an interval of $0.3 \mathrm{~m}$ in both drillcores. The overall studied units cover a thickness of $85 \mathrm{~m}$, and intersect the uppermost part of the C5a Member, and the complete C5b and upper C5b members. Seven microfacies are recognized in thin sections according to lithology, sedimentary structures and geometry of the beds. The carbonate classifications of Dunham (1962) and Embry and Klovan (1972) were used for the description of components, matrix and cement. All thin sections were etched with red Alizarine and potassium ferricyanide for recognition of carbonate minerals. Following the basic concepts of sequence stratigraphy (Miall, 1997; Posamentier and Allen, 1999; Catuneanu et al., 2011), a lithofacies association hierarchy is defined as groups of genetically related microfacies that have been deposited by sedimentary processes active within an environment of deposition. The lithofacies association hierarchy is presented from deep (LFA1) to shallowing-upward (LFA6) evolutions. This LFA1/LFA6 hierarchy records a relatively conformable succession of genetically related beds or bedsets bounded by a flooding surface (Van Wagoner, 1995).

Forty-eight samples were selected for carbon and oxygen isotopic analyses. Carbonate powders were reacted with $100 \%$ phosphoric acid (density $>1.9$, Wachter and Hayes, 1985 ) at $75^{\circ} \mathrm{C}$ using a Kiel III online carbonate preparation line connected to a ThermoFinnigan 252 mass spectrometer. All values are reported in per mil relative to $\mathrm{V}$-PDB by assigning a $\delta^{13} \mathrm{C}$ value of $+1.95 \%$ and a $\delta^{18} \mathrm{O}$ value of $+2.20 \%$ to NBS19. The reproducibility of $\delta^{13} \mathrm{C}_{\mathrm{V}-\mathrm{PDB}}$ and $\delta^{18} \mathrm{O}_{\mathrm{V} \text {-PDB }}$ measurements is $0.04 \%$ and $0.07 \%$ o $(1 \sigma)$ successively. The $\mathrm{Sr}$ isotopes were measured on a VG54 multicollector mass spectrometer at the Université libre de Bruxelles (Belgium). The ${ }^{87} \mathrm{Sr} /{ }^{86} \mathrm{Sr}$ values were normalized to ${ }^{86} \mathrm{Sr} /{ }^{88} \mathrm{Sr}=0.1194$.

Major and trace concentrations were investigated on 15 samples, subjected to digestion in aqua regia which consists of a $0.5 \mathrm{~g}$ digested sample at $90{ }^{\circ} \mathrm{C}$ in a microprocessor controlling digestion block for $2 \mathrm{~h}$. The solution was diluted and analyzed by ICP/MS using a Perkin Elmer SCIEX ELAN ICP/MS at Activation Laboratories Ltd. in Canada.

\section{Results}

\subsection{New lithological observations}

Sampling covers the whole C5 Formation, except for the lowermost part of the C5a Member missing in this study. The C5 Formation is described lithologically from oldest to youngest above.

The uppermost part of the C5a Member consists of finely bedded, dark-colored, massive dolomitic limestones, including centrimeter-scale oolitic grainstone and calcpelitic layers (Fig. 3A). Oolites are predominantly spherical or ovoid, and consist of tangential and composite grains. Microbial mats are preserved in the limestones. Millimeter-scale pseudomorphs after gypsum and cherts are observed. The contact with the overlying C5b Member is gradational.

The C5b Member consists of $>52$ m-thick dominantly dolomitic limestones with centimeter to decimetre-scale interbeds of calcpelites and dolomitic shales. A fault is present at $50 \mathrm{~m}$ of depth in the GX6c drillcore (Fig. 3B). The C5b Member begins with finely bedded dark greenish calcpelites and dark grey massive and laminar limestones with centimeter-to decimeter-thick, well sorted, dark grey to dark oolitic grainstones, named "Kisantu Oolite", locally silicified (Figs. 3A and 4A-C). Oolites are spherical or ovoid, and consist of tangential, composite and aggregate grains. Lumps and rare and oncolites are observed. Filamentous cyanobacterium Obruchevella parva is observed in the nucleus of the oolites (Plate 1B-D; see Alvarez et al., 1995 for discussion). Centimeter-scale greenish dolomitic shale layer is present at the base. The uppermost of the C5b Formation consists dominantly of finely bedded dark-colored massive and laminar limestones, often dolomitic, with 


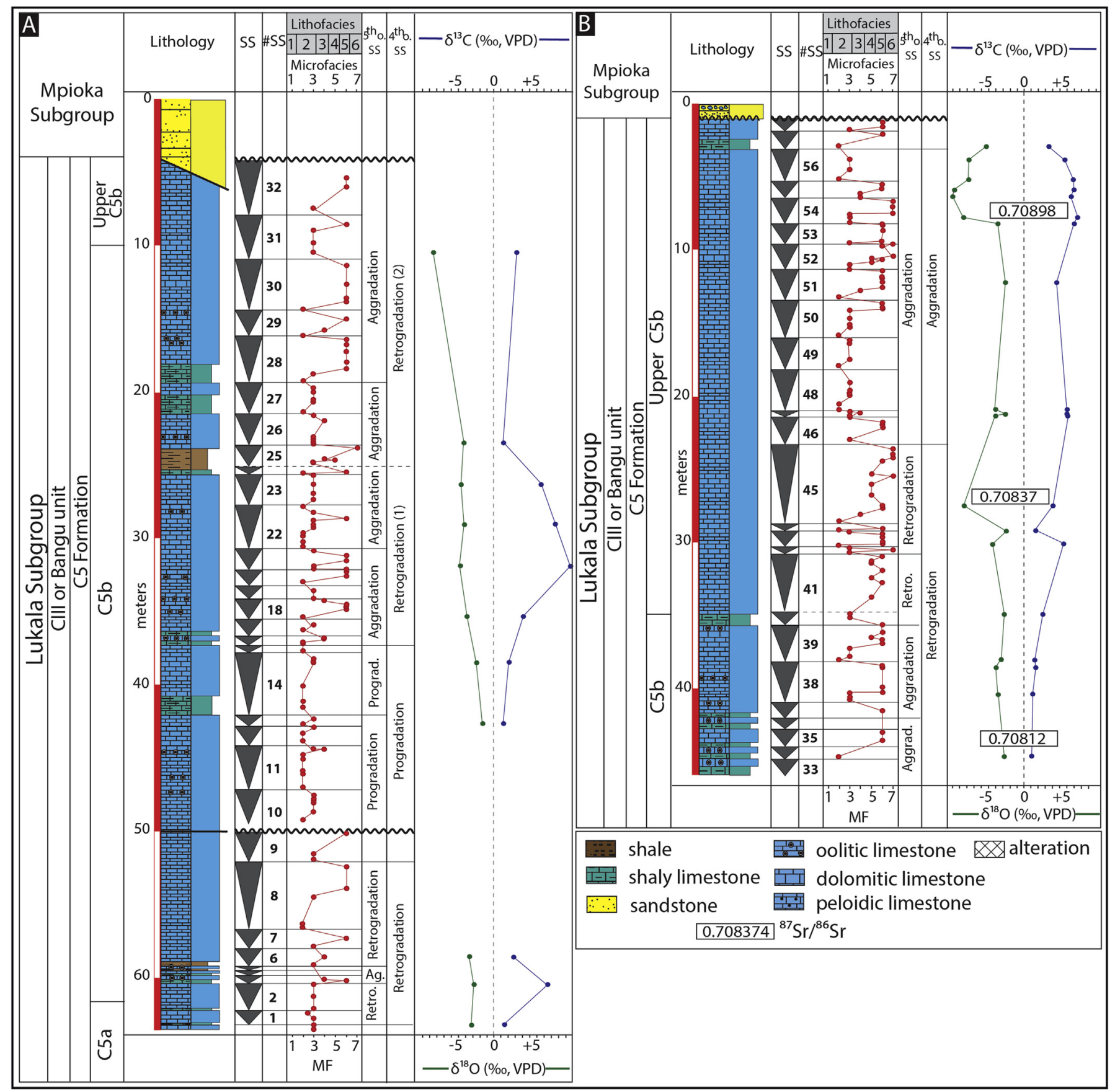

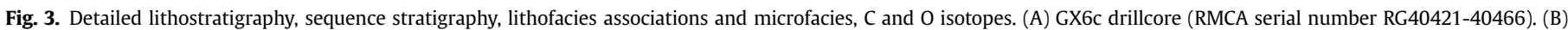
GN7/9a drillcore (RMCA serial number RG40178-40198). Both drillcores are located west Kininga river.

locally small-scale LLH-type stromatolites (Laterally Linked Hemispheroids; Logan et al., 1964) and centimeter-to decimeter-thick well sorted dark grey to dark oolitic grainstones, Low-angle crosslaminations, rare ripples, erosional gutter casts, desiccation crack surfaces, dark grey lime mudstones with whitish nodules of pseudomorphic gypsum and anhydrite, and the presence of yellow to reddish brown hardgrounds. The contact with the overlying upper C5b Member is gradational and corresponds with the transition of dark limestones towards pale grey to white limestones. Locally, a multidecimeter-thick pale greenish-grey dolomitic shale bed marks the contact. The lowermost part of the upper C5b Member, i.e., the upper C5b1 submember, consists of approximately 40 m-thick of light to dark greyish laminar to nodular dolomitic limestones, locally dolostones, with frequent ripples, yellow to reddish brown hardgrounds and desiccation surfaces, calcretes, reddish to dark grey dolomitic shales, and dark grey calcpelites (Fig. 3B). Nodules of pseudomorphic anhydrite and gypsum are common. The upper C5b2 submember is not investigated in this paper due to its absence related to erosion by the Mpioka Subgroup.

\subsection{Lithofacies and microfacies analyses}

Seven microfacies (MF1 to MF7) are recognized in the C5 Formation from thin-sections. They are grouped into six lithofacies 


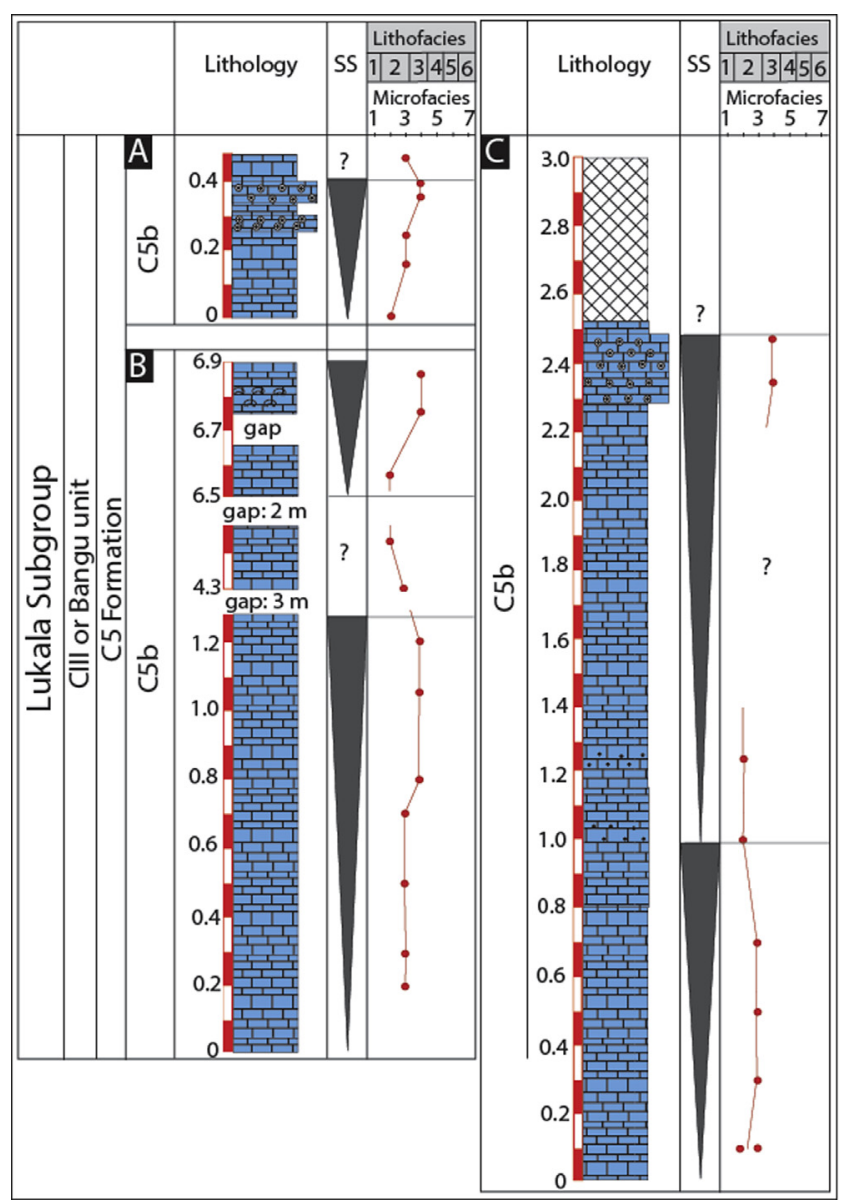

Fig. 4. Detailed lithostratigraphy, sequence stratigraphy, lithofacies associations and microfacies. (A) Ngufu train station (GPS coordinate: S5 $03^{\prime} 09.3^{\prime \prime} / \mathrm{E} 15^{\circ} 06^{\prime} 48.9^{\prime \prime}$ ). (B) Ngufu quarry (GPS coordinate: $5^{\circ} 03^{\prime} 29.9^{\prime \prime} / \mathrm{E} 15^{\circ} 06^{\prime} 80.2^{\prime \prime}$ ). (C) Kavuaya quarry (GPS coordinate: $\left.5^{\circ} 04^{\prime} 33.3^{\prime \prime} / \mathrm{E} 15^{\circ} 07^{\prime} 38.3^{\prime \prime}\right)$.

associations, LFA-1 to LFA-6, according to their lithology, sedimentary structures, textures, and fossil contents, and interpreted deposition in distinct environments. Lithofacies associations and microfacies categories are summarized in Table 1, and shown in Figs. 3 and 4.

\subsubsection{Lithofacies association 1 (LFA-1)}

Lithofacies association 1 includes oolitic packstone-grainstone
(MF1). It consists of dark grey, medium to well sorted calcarenites with tiny and indistinct cross-laminations. In thin section, MF1 consists of 1-2 mm-thick layers of well sorted oolitic packstone and grainstone (Plate $2 \mathrm{~A}$ ). The oolites float in a tightly packed finegrained dark brown lime matrix (packstone) or in coarse-grained lighter-colored drusy sparitic cements (grainstone). The packstone and grainstone display wedge-shaped planar or trough crosslaminations. The oolites are predominantly spherical to ovoid with a dark microcrystalline fabric in the cortex or consist of concentric tangential grains, sometimes grouped in grapestones $(1 \mathrm{~mm}$ of diameter). Oolites are moderately elongated, flattened and stretched. Silicified yellow-colored oolites are locally observed. Associated with oolites, coalesced flattened peloids and debris of probable cyanobacterial mats (microbial chips) and vertical desiccation cracks are observed.

\subsubsection{Lithofacies association 2 (LFA-2)}

Lithofacies association 2 includes argillaceous mudstone (MF2) and laminated mudstone (MF3). MF2 consists of dark-grey, locally pale pinkish, massive limestone with thin argillaceous layers and stylolites. In thin section, the microfacies is characterized by a fine microcrystalline matrix (Plate 2A-B), locally replaced by a finegrained neomorphic microspar $(15-20 \mu \mathrm{m}$ in size). Following the degree of dolomitization, the matrix displays fine-grained hypidioto xenotopic dolomitic rhombs (5-10 $\mu \mathrm{m}$ in size). Wispy microbial mats, microbial chips, and isolated peloids, are also present. MF3 consists of laterally continuous dark grey, planar to wavy parallel, thin laminated limestone with oblique and cross-laminations. The laminations display dark brown micrite in a lighter microcrystalline matrix, locally with a peloidal fabric (Plate 2B). The matrix is partially replaced by a neomorphic microspar (15-30 $\mu \mathrm{m}$ in size) or, if dolomitized, by idio-to hypidiotopic dolomicrosparitic crystals (up to $50 \mu \mathrm{m}$ in size). This lithofacies association contains silt-sized quartz, irregular and flattened peloids (up to $20 \mu \mathrm{m}$ in diameter), randomly oriented swallowtail twins and platy rectangular laths of replaced gypsum, nodules and enterolithes of anhydrite replaced by calcitic cements.

\subsubsection{Lithofacies association 3 (LFA-3)}

Lithofacies association 3 is well developed in the C5b Member, and consists of a dark coarse-grained, well-sorted, cross-laminated oolitic grainstone (MF4). This microfacies consists of tightly-packed grainstone with spheroidal to ellipsoidal siliceous ooids and pisoids up to $50 \mu \mathrm{m}$ (Plate 2C) within wedge-shaped planar or low angle cross-laminations. Oolites are dominantly composed of multiplecoated and tangential laminae with either calcite or quartz in the cortex. Intergranular pores are occluded either by lighter-colored

Table 1

Summary of lithofacies association and microfacies characteristics for the C5 Formation (Democratic Republic of Congo).

\begin{tabular}{|c|c|c|c|}
\hline $\begin{array}{l}\text { Lithofacies } \\
\text { association }\end{array}$ & Microfacies & General description & $\begin{array}{l}\text { Depositional } \\
\text { environment }\end{array}$ \\
\hline LFA-1 & MF1 & $\begin{array}{l}\text { Light blue-grey, medium- to well-sorted, oolitic packstone-grainstone; planar or trough cross-laminations; peloids; } \\
\text { locally dolomitization; interparticular calcite cements; mudcracks }\end{array}$ & $\begin{array}{l}\text { Intertidal shoal } \\
\text { barrier }\end{array}$ \\
\hline \multirow[t]{2}{*}{ LFA-2 } & MF2 & $\begin{array}{l}\text { Thin-bedded dark-grey, pale pinkish argillaceous mudstone; microcrystalline micrite, local dolomitization; argillaceous } \\
\text { seams and stylolites; abundant replaced gypsum and anhydrite crystals }\end{array}$ & $\begin{array}{l}\text { Sub- to intertidal } \\
\text { lagoon }\end{array}$ \\
\hline & MF3 & $\begin{array}{l}\text { Dark grey planar to wavy parallel, laminated mudstone; oblique and cross-laminations; microcrystalline micrite, local } \\
\text { dolomitization; abundant replaced gypsum and anhydrite crystals }\end{array}$ & \\
\hline LFA-3 & MF4 & $\begin{array}{l}\text { Coarse-grained, well-sorted, tightly-packed oolitic grainstone; planar or low angle cross-laminations; local } \\
\text { dolomitization or silicification; interparticular calcite cements; mudcracks }\end{array}$ & Intertidal beach \\
\hline LFA-4 & MF5 & $\begin{array}{l}\text { Thin microbially planar and wavy parallel laminated mudstone; microcrystalline micrite, local dolomitization; fenestrae; } \\
\text { abundant replaced gypsum and anhydrite crystals; mudcracks; pedogenic crusts }\end{array}$ & $\begin{array}{l}\text { Inter- to supratidal } \\
\text { mudflat }\end{array}$ \\
\hline LFA-5 & MF6 & $\begin{array}{l}\text { Evaporitic dolomudstone; equigranular xeno- to hypidiotopic dolomitic matrix; brownish to bluish white replaced } \\
\text { gypsum crystals, nodular anhydrite and interbeds of anhydrite, chicken-wire structures; mudcracks; hardgrounds }\end{array}$ & Supratidal sabhka \\
\hline LFA-6 & MF7 & $\begin{array}{l}\text { Dark, rarely yellowish-orange, millimetric-thick crusts of slightly undulated laminations; in situ brecciation of } \\
\text { dolomitized limestone; local oolites and peloids; abundant replaced gypsum and anhydrite crystals; mudcracks }\end{array}$ & Paleosoil \\
\hline
\end{tabular}


drusy sparry calcite cements or by micro- and megacrystalline quartz cements. Occurrence of helically coiled microfossil Obruchevella parva is recognized in the nucleus of the silicified oolites (see Alvarez et al., 1995 for discussion) (Plate 1A-D). Most skeletal grains are occluded by randomly oriented platy rectangular laths and castle-shaped pseudomorphs of evaporitic crystals (gypsum replaced by anhydrite). Desiccation cracks, rare lamellar and meniscus sparry cements are also observed.

\subsubsection{Lithofacies association 4 (LFA-4)}

Lithofacies association 4 consists of microbially laminated dark grey mudstone with submillimeter, irregular or continuous planar and wavy parallel laminations (MF5) (Plate 2D). In thin section, the microfacies displays dark brown microcrystalline micritic laminations in light dark grey-brown micritic or neomorphosed microsparitic fenestral matrix (Plate 2D). Fenestrae characterized by small spar-filled cavities and larger irregular voids are occluded in the microbial laminae. Platy rectangular laths, castle-shaped, nodules and enteroliths of pseudomorphs of evaporitic crystals (gypsum replaced by anhydrite) are also observed. Subvertical cracks, locally forming an in-situ breccia, filled by sparry cements cross the microbial laminations. Yellowish-orange to brown centimeter-sized discontinuous hardground surfaces with signs of abrasion and corrosion are present, and consist of millimeter-thick iron hydroxide (goethite, limonite determined by XRD) crusts (see lithofacies association 5 for explanation).

\subsubsection{Lithofacies association 5 (LFA-5)}

Lithofacies association 5 only includes the evaporitic dolomudstone microfacies (MF6).

MF6 is a mud-supported dark-grey dolomitic limestone dominantly composed of brownish to bluish white nodular anhydrite with interbeds of anhydrite. Anhydrite is commonly replaced by a light drusy sparry cement. A few microcrystals of anhydrite are still present as inclusions in the cements. Various types of gypsum crystals such as lenticular, lozenge-shaped, swallowtail twinned, and platy rectangular are common (Plate 2D). Small-sized nodules and chicken-wire structures show loosely packed aggregates of tiny platy rectangular laths and stellate crystals (Plate 2E-F). Locally, 1$2 \mathrm{~cm}$-thick layers of massive anhydrite are mixed with the dolomudstone. The matrix of the latter is composed of equigranular xeno-to hypidiotopic dolomitic crystals (5-15 $\mu \mathrm{m}$ in size) in nonplanar fabrics. Desiccation cracks (20-200 $\mu \mathrm{m}$ of width) filled by drusy sparry cements and hardgrounds are also present.

\subsubsection{Lithofacies association 6 (LFA-6)}

Lithofacies association 6 is rare in the studied series, and only includes the calcrete microfacies (MF7). MF7 consists of dark, rarely yellowish-orange, millimeter-thick crusts of slightly undulated laminations, and in-situ breccia of dolomitized limestone. Abundant desiccation cracks are common. In thin section, the microfacies shows light grey brown fine-to medium-grained dolomitic mudstone, locally dolomitized wackestone with oolites and peloids and a dense dolomicrite forming thin crusts (Plate 2F). Crescentic veins of sparite form an in situ breccia. Sand-sized dense dolomicritic 'glaebules' and dolomicrite coatings are present. Associated matrix exhibits hypidiotopic dolomitic crystals ( $20 \mu \mathrm{m}$ in size). Rare laminations are planar parallel to crossed. Pseudomorphs after anhydrite (rosettes, laths, or fibrous replaced gypsum) are fairly common. Meniscus cements are observed on the rims of the coated grains.

\subsection{Sequence stratigraphy}

Sequence stratigraphy emphasizes facies relationships and stratal architecture within a chronological framework (Miall, 1997; Posamentier and Allen, 1999; Catuneanu et al., 2011). Due to the difficulty in identifying a lithofacies hierarchy in carbonates, a sequence standard of microfacies is defined by the geometry of the systems tracts and the sediment supply controlled by sea-level changes, the ability of carbonate production to pace the increase of accommodation space, and the types of stratigraphic surfaces. Applying this systematically to our recognized shallowing-upward standard sequences (MF1-MF7), 58 fifth-order elementary parasequences have been identified in the C5 Formation (Fig. 3). Each parasequence is reset when the lithofacies association curve back towards the LFA1 to LFA2.

The Gx6c drillcore contains 32 elementary parasequences, each of them recording a shallowing-upward evolution of sedimentation (Fig. 3A). The C5a Member presents two elementary parasequences $1-2$ included in a retrogradational stacking pattern with an average cycle thickness of $1.4 \mathrm{~m}(\mathrm{n}=2)$. The $\mathrm{C} 5 \mathrm{~b}$ to upper C5b members contain seven parasequence sets (fourth-order) as follows: 3-5, $6-8,10-13,14-15,16-21,22-27$, and $28-32$. The parasequence set $3-5$ shows an aggradational stacking pattern with an average cycle thickness of $0.3 \mathrm{~m}(\mathrm{n}=3)$. The parasequence set $6-8$ records a retrogradational trend with an average cycle thickness of $3.8 \mathrm{~m}$ $(\mathrm{n}=3)$. The parasequence sets $10-13$ and $14-15$ show two progradational trends with an average cycle thicknesses of $1.7 \mathrm{~m}$ $(\mathrm{n}=4)$ and $2.2 \mathrm{~m}(\mathrm{n}=2)$ respectively. The parasequence set 16-21 has an average cycle thickness of $1.1 \mathrm{~m}(\mathrm{n}=6)$. The elementary parasequences 22-31 show three aggradational stacking patterns or parasequence sets with an average cycle thicknesses of $1.8 \mathrm{~m}$ $(\mathrm{n}=3), 1.8(\mathrm{n}=3)$ and $2.9 \mathrm{~m}(\mathrm{n}=5)$.

The GN7-9a contains 26 elementary parasequences without significant changes of sedimentation (Fig. 3B). The uppermost C5b Member is represented by parasequence sets (fourth-ordrer) 33-36 and 37-39 showing aggradational trends. Their average cycle thicknesses are $0.9 \mathrm{~m}(\mathrm{n}=4)$ and $2.2 \mathrm{~m}(\mathrm{n}=3)$. The C5bupper C5b boundary shows a retrogradational stacking pattern (parasequences 40-41) with an average cycle thickness of $2.6 \mathrm{~m}$ $(n=2)$. The upper C5b Member records two successions of parasequence sets that consisting of $42-45$ and $46-56$. The parasequence set $42-45$ points to an aggradational trend with an average cycle thickness of $1.9 \mathrm{~m}(\mathrm{n}=4)$. The parasequence set 46-56 records an aggradational trend with an average cycle thickness of $1.8 \mathrm{~m}(\mathrm{n}=11)$.

\subsection{C, $\mathrm{O}$ and Sr isotopic compositions}

The $\mathrm{C} 5 \mathrm{a} / \mathrm{C} 5 \mathrm{~b}$ boundary is marked by a positive $\delta^{13} \mathrm{C}$ excursion from $+1.5 \%$ o to $+7.5 \%$, while the $\delta^{18} \mathrm{O}$ values are stable $(-3.2 \%$ o to $-2.9 \%$ ) (Fig. 3A). The C5b unit displays a range of $\delta^{13} \mathrm{C}$ and $\delta^{18} \mathrm{O}$ varying between $+1.3 \%$ and $+10.8 \%$, and $-4.8 \%$ and $-1.7 \%$ respectively (Fig. $3 \mathrm{~A}$ ). The $\mathrm{C} 5 \mathrm{~b} /$ upper $\mathrm{C} 5 \mathrm{~b}$ boundary is marked by a negative isotopic shift of the $\delta^{13} \mathrm{C}(+1.5 \%$ to $-3.1 \%)$ and $\delta^{18} \mathrm{C}$ $\left(-3.1 \%\right.$, to $-8.6 \%$ ) followed by a return to positive $\delta^{13} \mathrm{C}$ values at the base of the upper part of the C5 Formation (from $-3.1 \%$ to $+2.8 \%$ ) (Fig. 3B). The upper part of the C5b Member displays higher $\delta^{13} \mathrm{C}$ values with a mean value ranging around $+5.4 \%$ (Fig. 3B). The oxygen isotope ratio shows a decrease from base to the top with $\delta^{18} \mathrm{O}$ values varying from $-2.8 \%$ to $-10.0 \%$ (Fig. 3A-B). The strontium isotope ratio of the one sample analyzed in the C5b Member is 0.708118 , and of the two samples of the upper C5b Member are 0.708374 and 0.708982 , respectively (Fig. 3B).

\subsection{Whole rock geochemistry}

An overview of the geochemical dataset is presented in Table 2 . Each element is normalized with $\mathrm{Al}$, and the enrichment factor is 
Table 2

Carbon, oxygen and strontium isotopic compositions and elemental geochemical data on the C5 Lukala carbonates. Abbreviation: VPDB, Vienna Pee Dee Belemnite.

\begin{tabular}{|c|c|c|c|c|c|c|c|c|c|c|c|c|c|c|c|c|}
\hline Sample & Drillcore & Member & $\begin{array}{l}\delta^{13} \mathrm{C}(\%, \\
\mathrm{VPDB})\end{array}$ & $\begin{array}{l}\delta^{18} \mathrm{O}(\%, \\
\mathrm{VPDB})\end{array}$ & ${ }^{87} \mathrm{Sr} /{ }^{86} \mathrm{Sr}$ & $\mathrm{Ca}(\%)$ & $\begin{array}{l}\mathrm{Mg} \\
(\%)\end{array}$ & $\mathrm{Al}(\%)$ & $\mathrm{Fe}(\%)$ & $\begin{array}{l}\mathrm{Mn} \\
(\mathrm{ppm})\end{array}$ & $\begin{array}{l}\mathrm{Sr} \\
(\mathrm{ppm})\end{array}$ & $\begin{array}{l}\mathrm{Rb} \\
(\mathrm{ppm})\end{array}$ & $\begin{array}{l}\mathrm{Cd} \\
(\mathrm{ppm})\end{array}$ & $\begin{array}{l}\mathrm{Cr} \\
(\mathrm{ppm})\end{array}$ & $\begin{array}{l}\mathrm{Cu} \\
(\mathrm{ppm})\end{array}$ & $\begin{array}{l}\mathrm{Ni} \\
(\mathrm{ppm})\end{array}$ \\
\hline BCK112 & GN7/9a & $\begin{array}{l}\text { upper } \\
\text { C5b }\end{array}$ & 5.8 & -7.7 & - & 18.4 & $>10.0$ & 0.9 & 0.3 & 1710 & 66.0 & 2.4 & 0.6 & 35.8 & 28.0 & 13.0 \\
\hline ВСК99 & GN7/9a & $\begin{array}{l}\text { upper } \\
\text { C5b }\end{array}$ & 7.0 & -3.7 & 0.708982 & 18.9 & $>10.0$ & 1.3 & 0.4 & 278 & 108.0 & 3.4 & 0.3 & 16.3 & 1.9 & 17.9 \\
\hline BCK61 & GN7/9a & $\begin{array}{l}\text { upper } \\
\text { C5b }\end{array}$ & 6.0 & -4.0 & & 17.9 & $>10.0$ & 1.0 & 0.4 & 504 & 82.4 & 4.9 & 0.6 & 21.3 & 21.4 & 14.5 \\
\hline BCK44 & GN7/9a & $\begin{array}{l}\text { upper } \\
\text { C5b }\end{array}$ & 4.0 & -8.6 & 0.708374 & 34.1 & 2.8 & 0.1 & 0.2 & 264 & 124.0 & 0.5 & 0.2 & 7.9 & 2.2 & 22.4 \\
\hline BCK43 & GN7/9a & $\begin{array}{l}\text { upper } \\
\text { C5b }\end{array}$ & - & - & - & 5.7 & 6.6 & 0.2 & 0.1 & 15 & 38.4 & 1.4 & 0.3 & 7.6 & 0.9 & 20.2 \\
\hline BCK41 & GN7/9a & $\begin{array}{l}\text { upper } \\
\text { C5b }\end{array}$ & - & - & - & 10.7 & $>10.0$ & 4.0 & 1.4 & 241 & 72.2 & 68.4 & 0.2 & 56.6 & 7.0 & 31.0 \\
\hline ВСК34 & GN7/9a & $\begin{array}{l}\text { upper } \\
\text { C5b }\end{array}$ & 5.6 & -4.4 & - & 20.4 & $>10.0$ & 0.1 & 0.2 & 131 & 73.6 & 0.6 & 0.0 & 10.0 & 1.9 & 10.0 \\
\hline ВСК32 & GN7/9a & $\begin{array}{l}\text { upper } \\
\text { C5b }\end{array}$ & - & - & - & 3.4 & 7.1 & 0.1 & 0.1 & 19 & 21.7 & 0.9 & 3.5 & 7.2 & 10.0 & 95.7 \\
\hline BCK22 & GN7/9a & $\begin{array}{l}\text { upper } \\
\text { C5b }\end{array}$ & 2.8 & -2.8 & - & 10.2 & $>10.0$ & 3.5 & 1.2 & 214 & 61.1 & 32.2 & 0.4 & 43.8 & 37.7 & 26.1 \\
\hline ВСК002 & GN7/9a & $\begin{array}{l}\text { upper } \\
\text { C5b }\end{array}$ & 1.1 & -2.8 & 0.708118 & 19.6 & $>10.0$ & 0.1 & 0.1 & 168 & 62.7 & 0.3 & 5.0 & 8.5 & 6.9 & 14.0 \\
\hline ВСК290 & GX6c & $\mathrm{C} 5 \mathrm{~b}$ & 1.3 & -4.2 & - & 13.9 & $>10.0$ & 1.3 & 1.6 & 476 & 78.6 & 33.4 & 0.1 & 24.0 & 20.0 & 34.8 \\
\hline ВСК252 & GX6c & C5b & 4.1 & -3.9 & - & 2.5 & 8.3 & 4.0 & 7.0 & 321 & 60.2 & 62.7 & 0.1 & 66.0 & 32.0 & 85.4 \\
\hline ВСК206 & GX6c & $\mathrm{C} 5 \mathrm{~b}$ & 7.5 & -2.9 & - & 21.4 & $>10.0$ & 0.0 & 0.4 & 607 & 118.0 & 0.6 & 0.1 & 4.0 & 9.6 & 38.7 \\
\hline ВСК201 & GX6c & C5a & 1.5 & -3.2 & - & 16.2 & $>10.0$ & 0.9 & 2.7 & 1200 & 128.0 & 12.8 & 0.1 & 14.0 & 28.1 & 52.3 \\
\hline
\end{tabular}

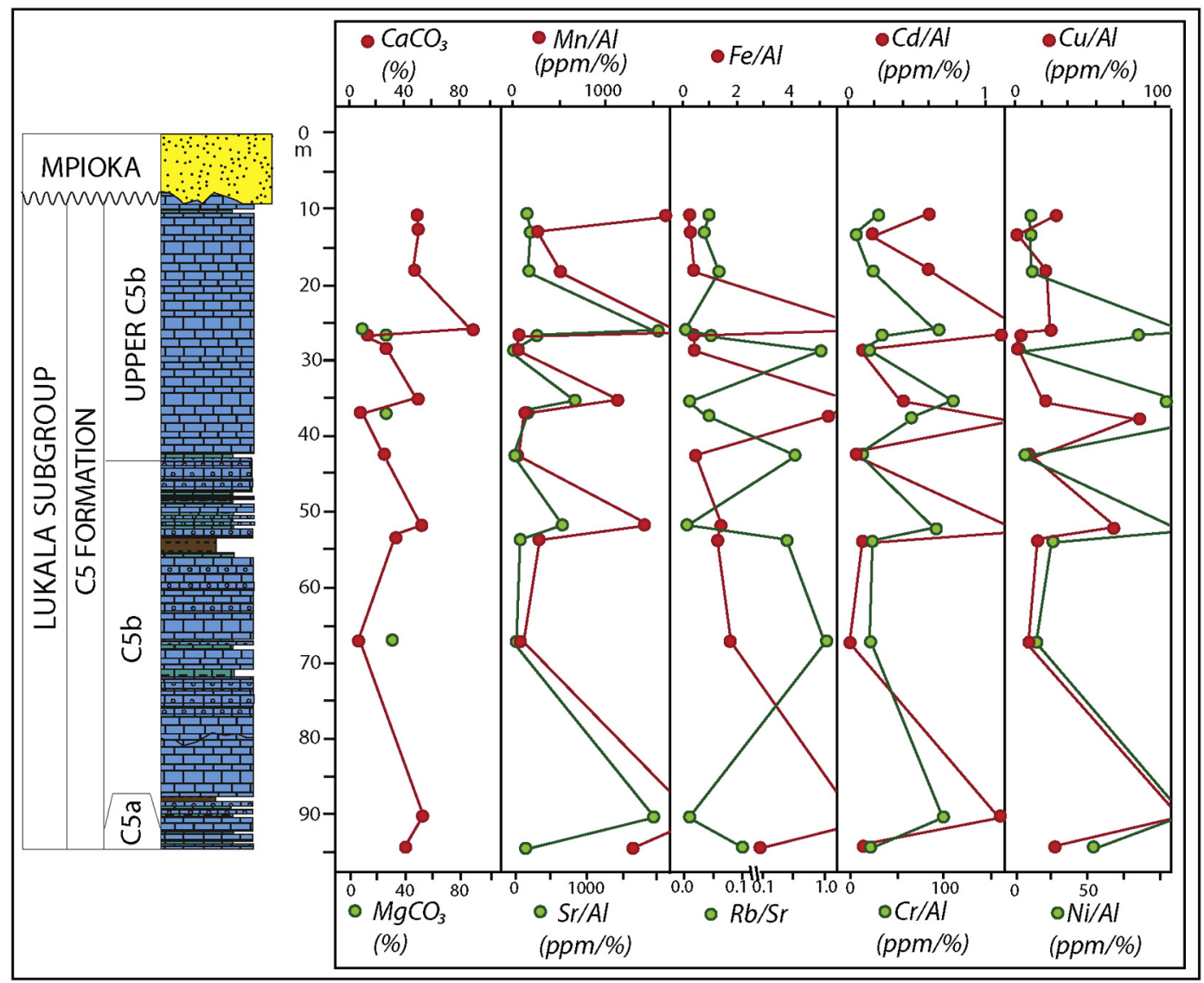

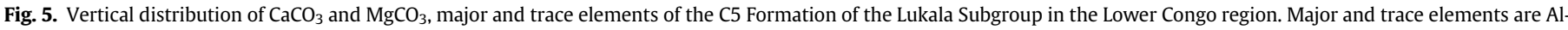
normalized.

compared with Post Archean Australian Shales (PAAS). All data plotted in Fig. 5 and overall Al-normalized elements show similar patterns related to relative enrichments in $\mathrm{CaCO}_{3}$. The $\mathrm{CaCO}_{3}$ contents range between $6.3 \%$ and $85.3 \%\left(\mathrm{n}=14\right.$; av. $\left.\mathrm{CaCO}_{3}: 38.1 \%\right)$. $\mathrm{MgCO}_{3}$ contents are low to moderate with an average of $21.4 \%$ $(\mathrm{n}=4)$. These carbonate contents confirm the predominance of clay 
in dolomitized limestones. Pronounced enrichments in $\mathrm{Mn}, \mathrm{Fe}, \mathrm{Cd}$, $\mathrm{Cr}, \mathrm{Cu}$, and $\mathrm{Ni}$ concentrations are observed in the shaly limestones and organic-rich limestones of the $\mathrm{C} 5$ and upper $\mathrm{C} 5 \mathrm{~b}$ members respectively. The Mn concentrations range from $\sim 10$ to $\sim 1700 \mathrm{ppm}$ with an average of $440 \mathrm{ppm}(\mathrm{n}=14)$. The enrichment factors are relatively high compared to the PAAS. The Fe concentrations range between 0.1 and $7.0 \%$ with an average of $1.2 \%(n=14)$ and no enrichment compared to the PAAS is measured. The $\mathrm{Cd}$ and $\mathrm{Cr}$ concentrations range between 0.1 and $5.0 \mathrm{ppm}(\mathrm{n}=14$; av. $\mathrm{Cd}$ : $0.8 \mathrm{ppm}$ ), and between 4 and $66 \mathrm{ppm}$ ( $\mathrm{n}=14$; av. $\mathrm{Cr}: 23.1 \mathrm{ppm})$, and no enrichment factors are measured. The $\mathrm{Cu}$ and $\mathrm{Ni}$ concentrations range from below detection limit to $37.7 \mathrm{ppm}(\mathrm{n}=14$; av. $\mathrm{Cu}$ : $14.8 \mathrm{ppm}$ ) and from 10 to $96.0 \mathrm{ppm}(\mathrm{n}=14$; av. $\mathrm{Ni}: 34.0 \mathrm{ppm})$, and have enrichment factors that are depleted compared to PAAS. The Sr concentrations are relatively low with values ranging from 21.7 to $128 \mathrm{ppm}(\mathrm{n}=14)$. These values are in the same range than the data collected in the same stratigraphic unit in DRC published by Frimmel et al. (2006). The enrichment factors do not show any significant enrichment, except for four samples which show enrichment factors of 2-7 times over PAAS. $\mathrm{Rb} / \mathrm{Sr}$ ratios show an opposite trend compared to $\mathrm{Sr}$. $\mathrm{Rb} / \mathrm{Sr}$ ratios range from 0 to 1.04 $(\mathrm{n}=14)$.

\section{Interpretations and discussions}

\subsection{Depositional environments}

The lithofacies association 1 (LFA-1), including MF1, represents an intertidal barrier environment. Trough cross-laminations indicate deposition in high-energy environments such as sandy carbonate shoals. Concentric oolites are common in high-energy tidal channels, beaches, shorefaces and shoals (Burchette and Wright, 1992). Oolites and microbial chips apparently resulted from the reworking of fore-to back-barrier sediments (e.g., muds, cyanobacterial mats) by fair-weather waves and/or tides. Lithofacies association 2 (LFA-2) includes two distinct microfacies (MF2 and MF3). The argillaceous mudstone (MF2) is interpreted as lowenergy carbonate muds deposited in subtidal evaporitic environments. The pseudomorphs of anhydrite point to protected lagoonal conditions, probably barred by sandy shoals and reefs. The association with the laminated mudstone (MF3) suggests quiet intertidal and supratidal lagoonal settings colonized by cyanobacterial mats periodically reworked by intertidal currents. Arid conditions are recorded by the precipitation of salts such as gypsum and anhydrite. Lithofacies association 3 (LFA-3) represents oolitic sands (grainstones) deposited on a beach separating the supratidal mudflat and sabhka sediments from the evaporitic lagoons (Alvarez, 1995). Coated grains are well sorted by tidal currents during the abrasion, reworking and transport of lagoonal sediments. These grainstones were periodically submitted to subaerial exposition with desiccation cracks and possible pedogenic crusts. Lithofacies association 4 (LFA-4) represents shallow inter-to supratidal settings in evaporitic environments. Fenestrae and desiccation cracks indicate episodic subaerial exposures in intertidal settings (Grotzinger, 1986; Pratt et al., 1992). Lithofacies association 5 (LFA-5) represents supratidal evaporitic environments. Similar sediments are encountered in the recent shallow peritidal shelf and coastal sabkha of Abu Dhabi (Shearman, 1978). Lenticular, swallowtail twins and lath patterns are common in saline intertidal diagenesis (Cadwell, 1976) while nodules and chicken-wire structures are typical of sabkha settings, and result in the replacement of gypsum by anhydrite crystals in soft sediments by capillarity (Kinsman, 1969). Periodic emersions were recorded and in the form of polygonal desiccation cracks in inter- and supratidal beachrocks. Lithofacies association 6 (LFA-6) represents near-surface soil horizons or paleosoils, formed by the accumulation of $\mathrm{CaCO}_{3}$ and the oxidation of beachrock surfaces, with formation of iron oxyhydroxides in semi-arid climate conditions under sparse rainfall (Adatte et al., 2005). Occurrences of evaporites and breccia suggest that the sediment was exposed to desiccation, emersion and periods of dissolution in supratidal and continental environments. The presence of meniscus cements record temporary vadose conditions.

The lithofacies association succession (LFA-1 to LFA-6) constitutes the standard sequence ofC5 Formation, and integrates the variations of sea level, energy and salinity in the carbonate ramp. The interpretation of a ramp geometry is based on the vertical changes of microfacies (MF1 to MF7), which are grouped into a depositional cycle of open marine-to restricting-upward carbonate sequences (Fig. 6). The cycle is characterized by a LFA-1 to LFA-6 succession and a complete cycle begins with LFA- 1 . The cycle is typical of an inner ramp setting composed of a shallow oolitic sandy shoal-barrier stretching between an open-marine sea and a back-reef carbonate-evaporitic lagoon bordered by a coastal sabkha plain. This cycle has been described in the Republic of Congo (Alvarez and Maurin, 1991; Alvarez, 1995). A detailed depositional model for the inner carbonate-evaporitic ramp of the C5 Lukala unit is presented in Fig. 7.

Our microfacies analysis interprets the ooid-barrier shoals as high-energy back-reef inner-ramp sediments stretched between stromatolitic reefs and lagoonal facies. These ooids were formed in aragonite-saturated waters, and preferentially dolomitized by the back-reef brines. The lagoon was affected by dysoxic/anoxic brackish periods. It was rapidly flooded by well-oxygenated waters, which facilitated the development of benthic cyanobacterial 'seagrass' in the nearshore zones of the lagoon. The coastal shoreline zone is marked by high-energy waves and tides, salinity, and sealevel changes. Off-shore sand bars on a beach-strandplain belt were dominated by high wave energy and low tidal range. Beachrocks formation was frequent due to rapid cementation of sandy grains by possible aragonite and $\mathrm{Mg}$-calcite crystals growing in the interparticle spaces. Beachrock is common in low-latitude warmwater beaches of tropical and temperate environments, which are marked by emersions or marine regressions (Scoffin and Stoddard, 1983). The sabkha evaporites indicate an arid to semi-arid lowlatitude deposition. Extensive dolomitization, locally capped by calcrete surfaces at tops of the evaporitic cycles, occurred between the coastal and the reef zones. The C5 Formation sediments were seasonally subjected to precipitation and formation of calcrete surfaces and flooding by meteoric waters.

\begin{tabular}{|c|c|c|c|}
\hline \multicolumn{4}{|c|}{ Cycle of deposition } \\
\hline \multicolumn{2}{|l|}{ Environment } & \multicolumn{2}{|l|}{ Lithofacies association } \\
\hline Soil & & Calcrete (MF7) & LFA-6 \\
\hline Supratidal sabhka & & Evaporitic dolomudstone (MF6) & LFA-5 \\
\hline $\begin{array}{c}\text { Inter - to supr atidal } \\
\text { mudflat }\end{array}$ & 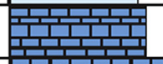 & $\begin{array}{l}\text { Microbially laminated } \\
\text { mudstone (MF 5) }\end{array}$ & LFA-4 \\
\hline Intertidal beach & 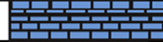 & Dolitic grainstone (MF4) & LFA-3 \\
\hline $\begin{array}{c}\text { sub- to intertidal } \\
\text { lagoon }\end{array}$ & 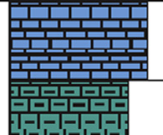 & Argillaceous mudstone (MF2) & LFA-2 \\
\hline $\begin{array}{c}\text { Inter tidal } \\
\text { shoal barrier }\end{array}$ & 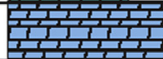 & $\begin{array}{l}\text { Dolitic (dolo)packstone/ } \\
\text { grainstone (MF1) }\end{array}$ & LFA-1 \\
\hline
\end{tabular}

Fig. 6. Vertical evolution of the microfacies (MF1 to MF7) from marine-to coastal carbonate evaporitic sequences. A cycle is characterized by a LFA- 1 to LFA- 6 succession that begins with LFA-1 (see text for discussion). 


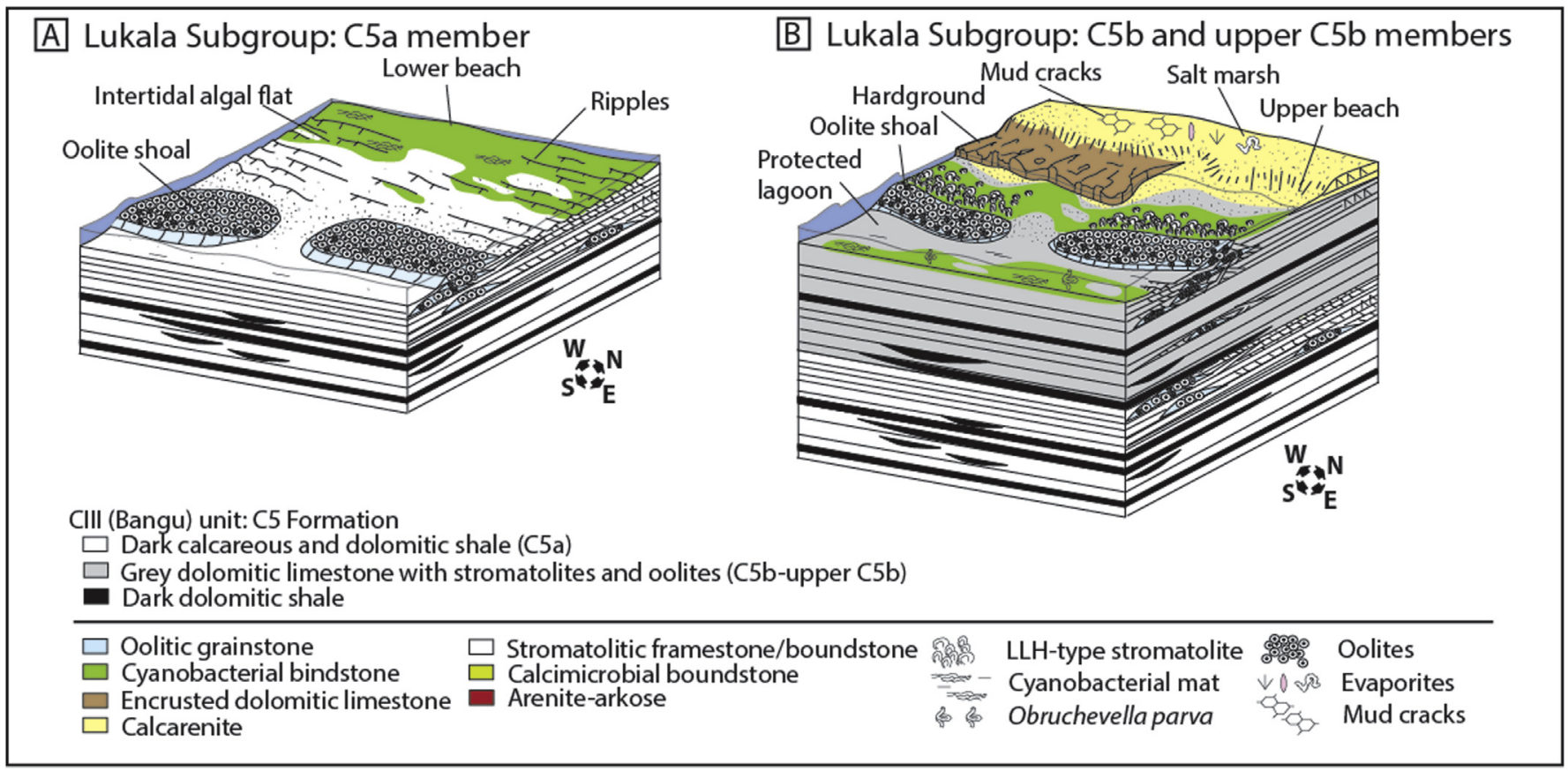

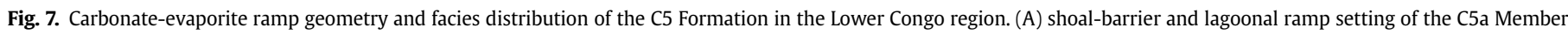

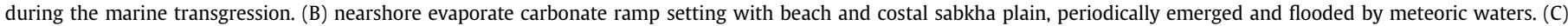
Unconformity marked at to Lukala and Mpioka boundary, and deposition of molasse-type deposits (see Frimmel et al., 2006 for discussion).

\subsection{Sea level evolution}

The C5 Lukala carbonates consist of $\sim 100$ m-thick carbonate and evaporitic sedimentation recording major upward shallowing sequences grouped in 58 fifth-order elementary parasequences. The sequences start with a marine inundation/transgression and the overall stacking patterns indicate a general retrogradational evolution through the recognition and stacking of fourth-order parasequence sets (Fig. 3). The initial marine transgression 'turns on' the carbonate factory with flooding of the ramp with sediments indicative of warm and shallow oolites and peloids. In contrast, a marine regression tends to shut down carbonate productivity, due to low accommodation space during sea-level fall and land-derived siliciclastic influx to the basin. The uppermost part of the C5a Member and the C5b Member preferentially exhibit retrogradational and aggradational stacking patterns, while the upper C5b Member shows progradational-aggradational stacking patterns. These patterns are common in Transgressive Systems Tracts (TST) and evaporitic carbonate succession exhibits generally retrogradational stacking patterns (Catuneanu et al., 2011). For the C5 carbonate ramp, an incomplete drawdown model is proposed due to the absence of thick salt horizons with selenite and halite (Tucker, 1991). During a short-term marine regression, precipitation of gypsum may take place in shallow lagoonal hypersaline waters, and is followed by a marine transgression flooding the basin, maintaining evaporitic deposition in the hypersaline lagoon. When the basin is completely flooded and fully connected to the open-marine waters, the hypersaline coastal sabkha environment could be very extensive. This depositional setting occurred during sea level highstand, and could have enhanced the deposition of organic-rich argillaceous carbonate and shale under dysoxia and anoxia conditions, in the lagoon center (Catuneanu et al., 2011).

The distribution of carbonate-evaporite cycle thicknesses (MF17) of the $C 5$ carbonates follow thin peritidal cycles. The uppermost part of the C5a Member shows an average cycle thickness of $1.6 \mathrm{~m}$ $(\mathrm{n}=2)$, while the average cycle thicknesses of the $\mathrm{C} 5 \mathrm{~b}$ and the upper C5b members are $1.7 \mathrm{~m}(\mathrm{n}=35)$ and $2.6 \mathrm{~m}(\mathrm{n}=21)$ respectively. This leads to an average thickness of $\sim 2.0 \mathrm{~m}$ for these peritidal cycles, which is common in the peritidal environments (Catuneanu et al., 2011; Franseen and Byrnes, 2012; Delpomdor et al., 2015a,b).

\subsection{Diagenetic considerations}

Evaluation of our isotopic data is a fundamental issue to assess the primary sedimentary record in seawater that may have been altered during recrystallization, dolomitization and other diagenetic processes (Brand and Veizer, 1980; Banner and Hanson, 1990). Various investigators have established a range of parameters in order to estimate the degree of chemical alteration of $\mathrm{C}$ and $\mathrm{Sr}$ isotopes in Precambrian carbonates (Brand and Veizer, 1980; Veizer et al., 1983; Derry et al., 1989, 1992; Asmerom et al., 1991; Kaufman et al., 1993). Because diagenetic alteration depends upon the composition of original carbonates as well as of the compositions of diagenetic fluids, it is likely impossible to devise a single set of criteria applicable to all Proterozoic carbonates. Each succession must therefore be independently evaluated within their depositional and diagenetic contexts. Post-depositional alteration can be evaluated using $\mathrm{Mn} / \mathrm{Sr}$ and $\mathrm{Fe} / \mathrm{Sr}$ geochemical ratios, depletion of $\mathrm{Ca}$ and $\mathrm{Sr}$, and replacement by $\mathrm{Mn}$ and Fe during exchange with diagenetic fluids (Brand and Veizer, 1980; Banner and Hanson, 1990). In our study, the ${ }^{87} \mathrm{Sr} /{ }^{86} \mathrm{Sr}$ vs. Sr concentration crossplot (cut off of 300 ppm of Sr; Halverson et al., 2005), is used as the limit for considering an isotope ratio as unaltered.

The $\delta^{13} \mathrm{C}$ vs. $\delta^{18} \mathrm{O}$ crossplot shows two distinct ranges of values related to the degree of dolomitization, which is particularly marked by a high $\mathrm{Mg} / \mathrm{Ca}$ ratio $(\mathrm{Mg} / \mathrm{Ca}>0.5$ ) in our samples (Fig. 8). The weakly dolomitized limestones are isotopically lighter than the dolomitic limestones that have been interpreted to be formed in mixed marine and/or meteoric waters. Dolomitization during 


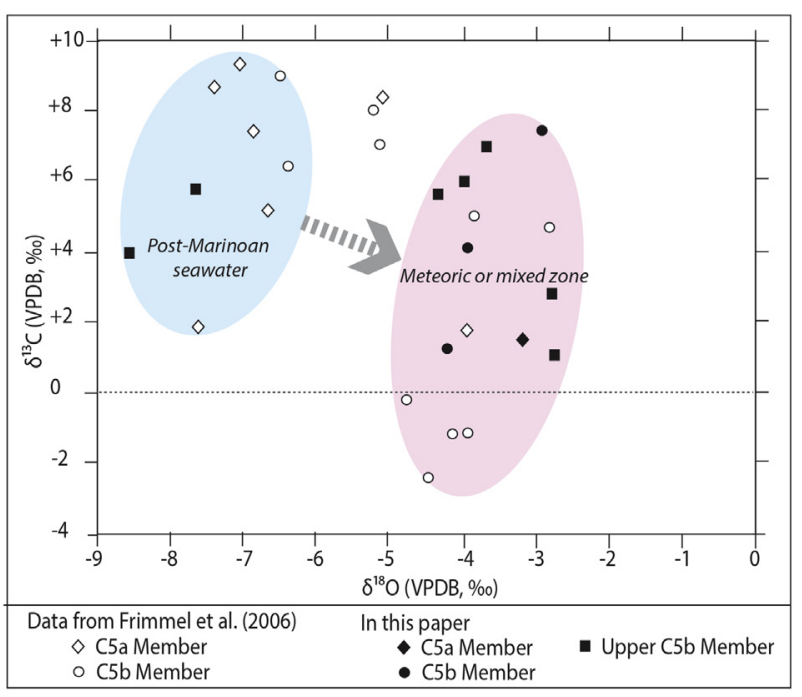

Fig. 8. $\delta^{13} \mathrm{C}$ vs $\delta^{18} \mathrm{O}$ crossplot showing the two sections with seawater compositions and least-altered isotopic compositions attributed to dolomitization. seawater-subsurface meteoric water interaction led to progressive enrichment of the subsurface fluids by $2-4 \%$ in their $\delta^{18} \mathrm{O}$ compositions (Land, 1980). Dolomitization probably occurred rapidly as indicated by the presence of finely crystalline pervasive dolomite (dolomicrosparites, see MF1/LFA-1), which indicates a minor alteration (Adabi and Rao, 1996).

Geochemical diagrams for the C5 Formation are shown in Fig. 9. Fig. 9A-B shows an increase of the ${ }^{87} \mathrm{Sr} /{ }^{86} \mathrm{Sr}$ ratio linked to the $\mathrm{Sr}$ leaching and $\mathrm{Mn}$ incorporation into the carbonate lattice during diagenesis. The high $\mathrm{Mn} / \mathrm{Sr}$ ratio is indicative of a depletion of the $\mathrm{Sr}$ and an enrichment of the Mn during meteoric diagenesis (Brand and Veizer, 1980; Banner and Hanson, 1990; Jacobsen and Kaufman, 1999, Table 2). Values close to zero for both figures suggest that these samples were unaltered by diagenetic fluids. Mn and Fe concentrations in the dolomitic limestones of the C5 Formation are relatively high by comparison to samples from the same stratigraphic level in DRC published by Frimmel et al. (2006). This higher distribution of these elements points to probable reducing conditions dominating the environment (Tucker and Wright, 1990). Trace elements may be hosted by various phases such as metal sulphides or in solid solution in pyrite. Consequently, in the absence of post-depositional replenishment of oxidizing agents, the elements engaged with sulphides are stable and do not move during

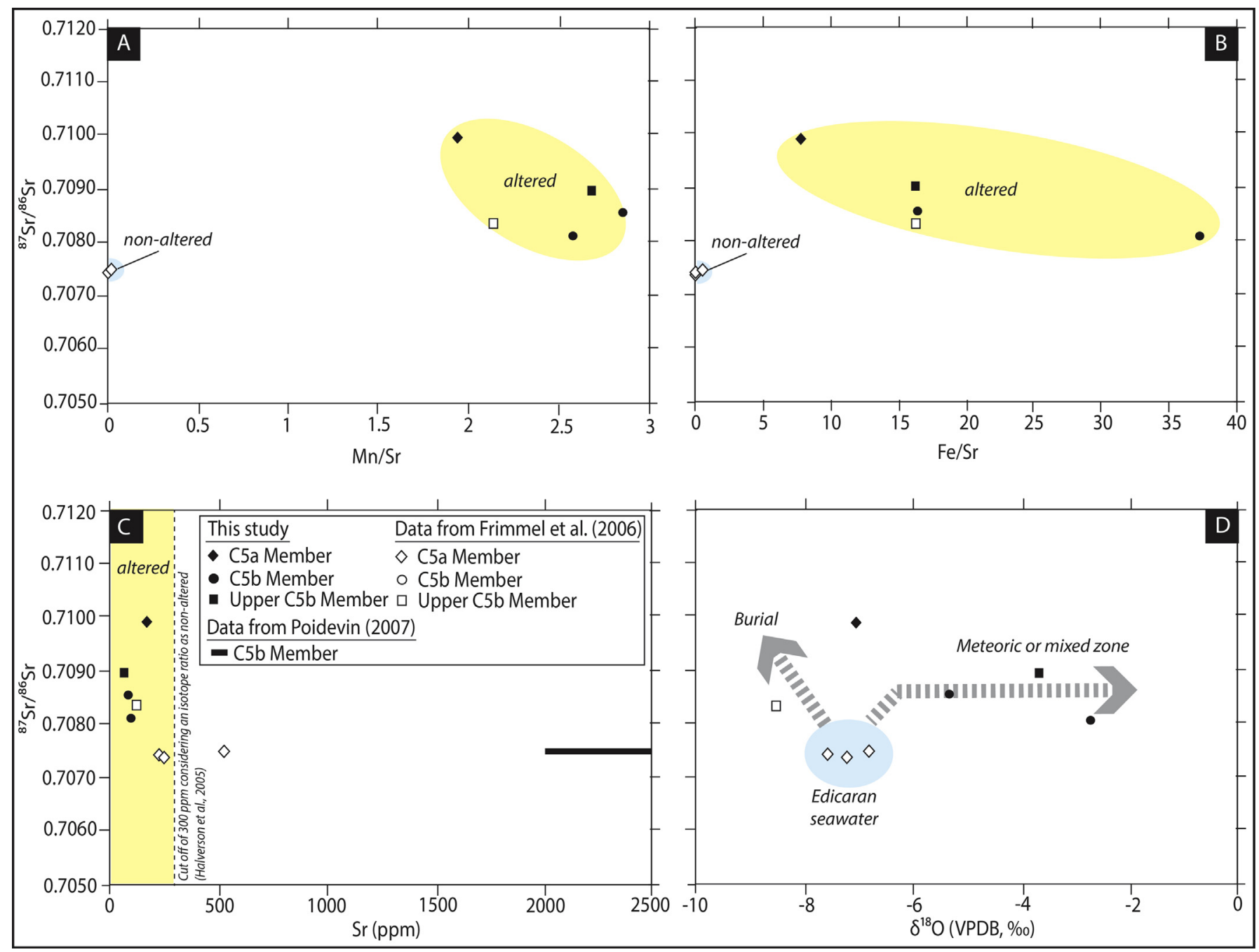

Fig. 9. ${ }^{87} \mathrm{Sr} /{ }^{86} \mathrm{Sr}$ vs. Mn/Sr, Fe/Sr and $\mathrm{Sr}$ concentration crossplots of isotope and geochemical data for the C5 Formation in DRC. 


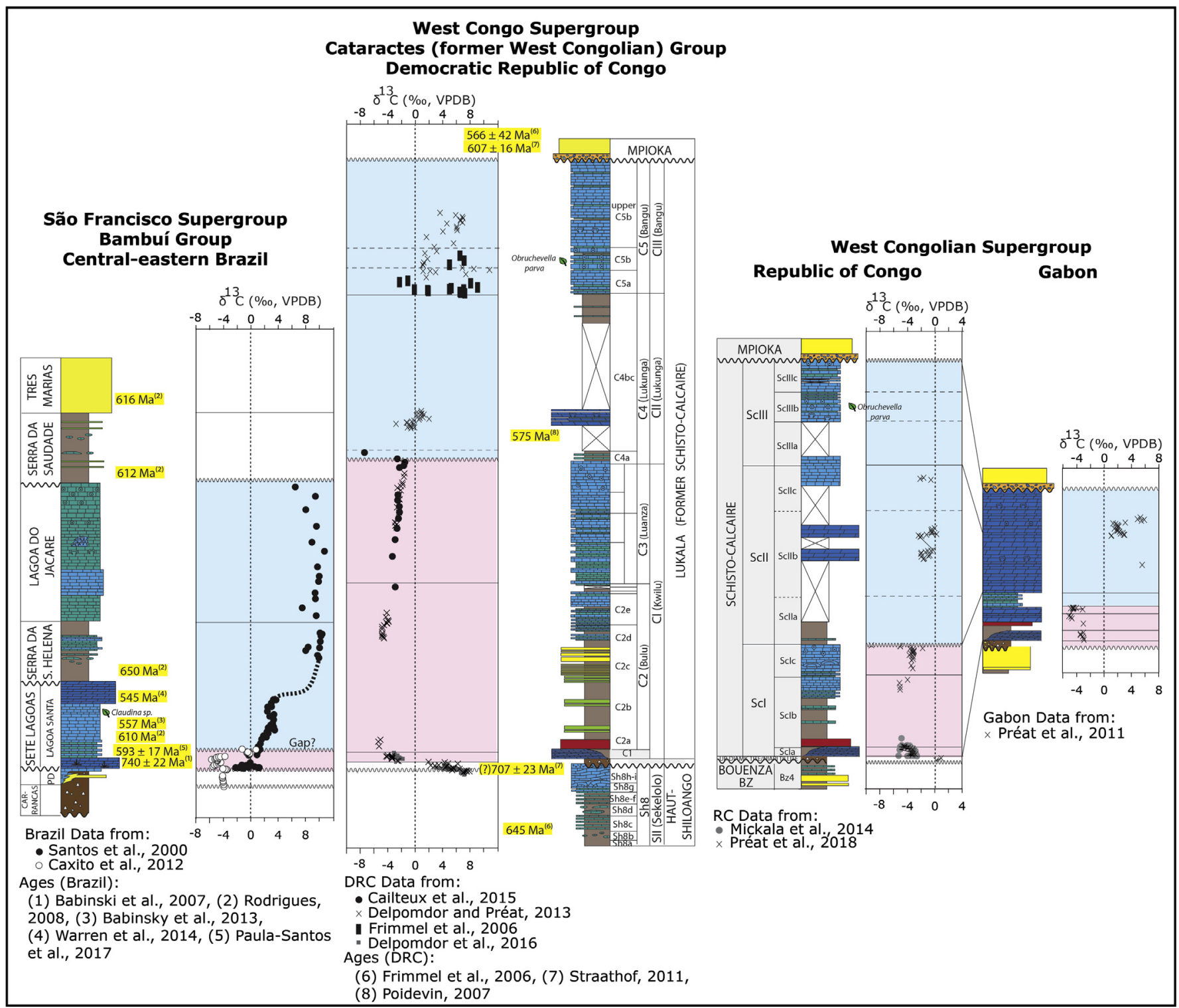

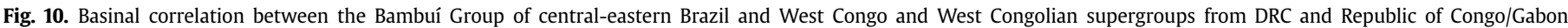

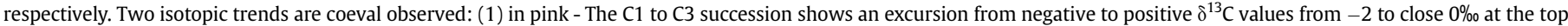

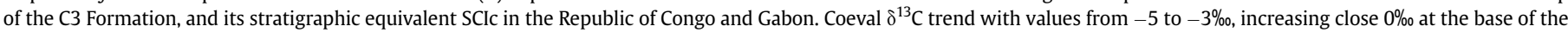

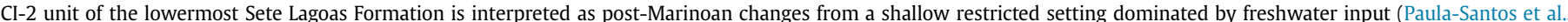

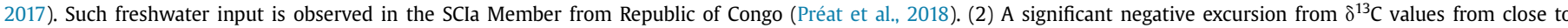

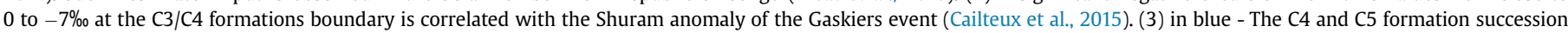

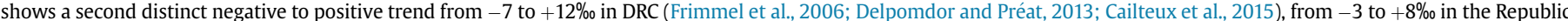

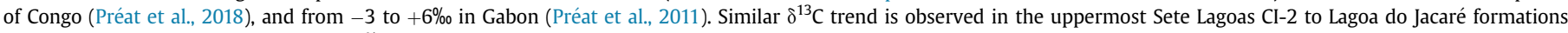

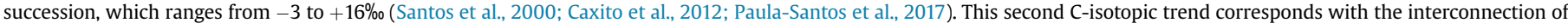

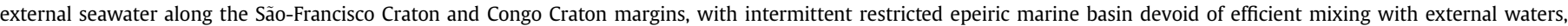

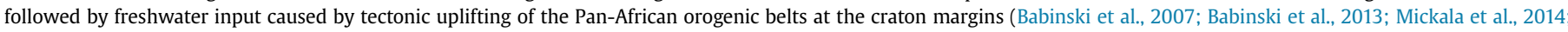
Rodrigues, 2008). (For interpretation of the references to colour in this figure legend, the reader is referred to the web version of this article.)

diagenesis (Tribovillard et al., 2006). This stability does not disturb the primary trace-element concentrations, which can thus be used as proxies for paleoredox conditions.

Fig. 9C shows that the increase of ${ }^{87} \mathrm{Sr} /{ }^{86} \mathrm{Sr}$ ratios is linked to the high $\mathrm{Sr}$ concentrations as a result of the mixed marine and/or meteoric waters during early diagenesis. This relationship does not preserve Sr composition of seawater and, therefore, cannot be used as a proxy for correlation. However, samples from the same unit published by Frimmel et al. (2006), close to the cut off of 300 ppm plot in the same ${ }^{87} \mathrm{Sr} /{ }^{86} \mathrm{Sr}$ ranges $(0.7074-0.7075)$ are considered as unaltered samples, representative of the seawater composition. In the absence of Sr isotope data in the Upper C5 Formation of DRC, we suggest that the primary signature on our samples is disturbed by diagenetic fluids directly after deposition.

\subsection{Paleoredox conditions}

Major and trace metals are generally used as proxies for the redox state in carbonate rocks (Frimmel, 2009; Schröder and Grotzinger, 2007; Meyer et al., 2012; Delpomdor et al., 2013; 

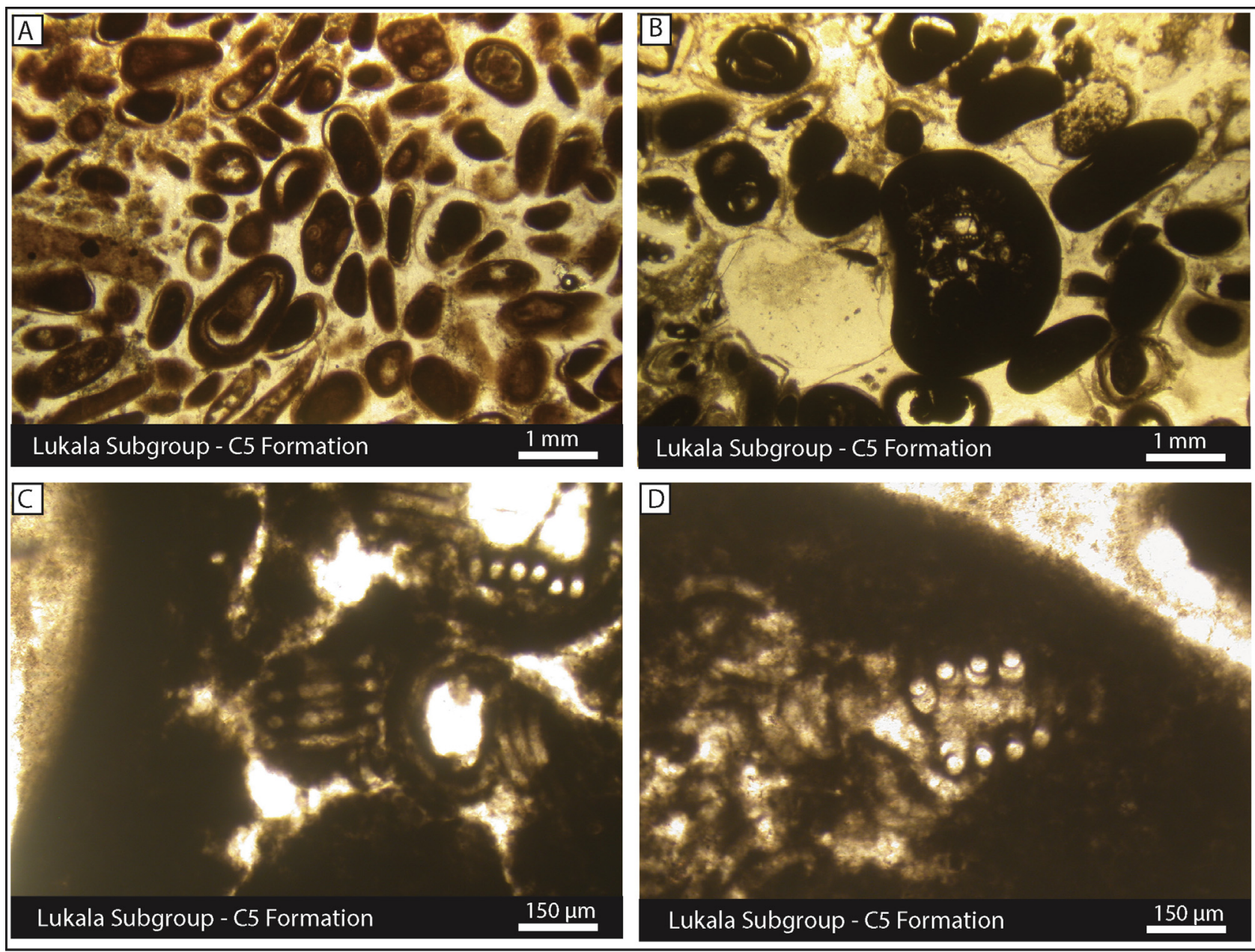

Plate 1. (A to B) Helicoidal cyanobacteria, attributed to Obruchevella parva Reitlinger (1959), observed in the MF4 of the C5b Member.

Hood and Wallace, 2015). Iron is generally induced through Fesulfide precipitation, biogenic or abiogenic oxidation of $\mathrm{Fe}(\mathrm{II})$ to form $\mathrm{Fe}(\mathrm{III})$, or via direct precipitation of $\mathrm{Fe}(\mathrm{II})$ carbonates or phosphates (e.g., Canfield et al., 1993; Raiswell and Canfield, 1998). In oxidized waters, $\mathrm{Fe}(\mathrm{III})$ is predominantly incorporated in $\mathrm{Fe}$ oxyhydroxides, while in reducing waters, Fe (III) is reduced in $\mathrm{Fe}(\mathrm{II})$, and is generally trapped by Fe-sulfide precipitation within sediments and waters (Tribovillard et al., 2006), or can be sequestered in Fe-carbonates only under special conditions (Canfield et al., 1993). Mn exhibits a similar pattern of redox cycling to $\mathrm{Fe}$ (Caplan and Bustin, 1999; Tribovillard et al., 2006). The C5 carbonates show a paired enrichment between Fe and Mn concentrations, and can be interpreted as the dissolution of Fe-Mn hydroxides during reducing conditions, and the removal of Fe and Mn by sulfides. However, the enhanced paired Fe and Mn enrichment could be also associated with the upwelling of anoxic basin brines (Meyer et al., 2012). The hydroxide scavenging of Fe and Mn is confirmed by the trace metals, which firstly are absorbed by FeMn-hydroxides, and then released upon reductive dissolution at or below the water-sediment interface. This results in the trace metals being available for capture by authigenic sulfides in reducing environments. $\mathrm{Cd}, \mathrm{Ni}$ and $\mathrm{Cu}$ co-enrichments are strong indicators of high biological productivity and reducing conditions. These trace metals are primarily delivered to sediments sorbed to organic matter (Tribovillard et al., 2006). The content of organic matter (OM) within the C5 carbonates is unknown, but due to the dark coloration of the rocks and the biological bloom of Obruchevella parva, a high OM content is not excluded. Cr has a strong affinity with Fe-hydroxides and oxides. In reducing waters, $\mathrm{Cr}$ can be dissolved in solution by the Fe-Mn-hydroxides and oxides scavenging the $\mathrm{Cr}$ (Piper, 1971). Accumulation of trace metals observed in both core sections of the $\mathrm{C} 5$ Formation could be indicative of short-time dysoxic and anoxic depositional conditions, rapidly followed by well-mixed oxidized waters. Alternatively, a pulse of alkaline water sourced from weathered continental material as a result of sealevel variations could significantly increase the trace metals concentrations in the sediments (Meyer et al., 2012).

\subsection{Age estimation of the C5 formation and paleogeography}

In the absence of straightforward radiometric dating the age of the C5 Formation cannot unequivocally be constrained. Although the C4 Formation has been ascribed a depositional age around $\sim 575$ Ma based on near-primary ${ }^{87} \mathrm{Sr} /{ }^{86} \mathrm{Sr}$ ratios (Poidevin, 2007), a similar attempt of "blind dating" of the overlying C5 Formation failed due to the low $\mathrm{Sr}$ concentrations in our samples. However, based on the reference Sr-isotope curves of seawater (Asmerom et al., 1991; Derry et al., 1994; Halverson et al., 2007), the leastaltered ${ }^{87} \mathrm{Sr} /{ }^{86} \mathrm{Sr}$ ratios $(0.7074-0.7075)$ of our samples suggest a depositional age for the C5 Formation in the interval 575-550 Ma (Frimmel et al., 2006).

Determination of finely crystalline pervasive dolomite, i.e. 

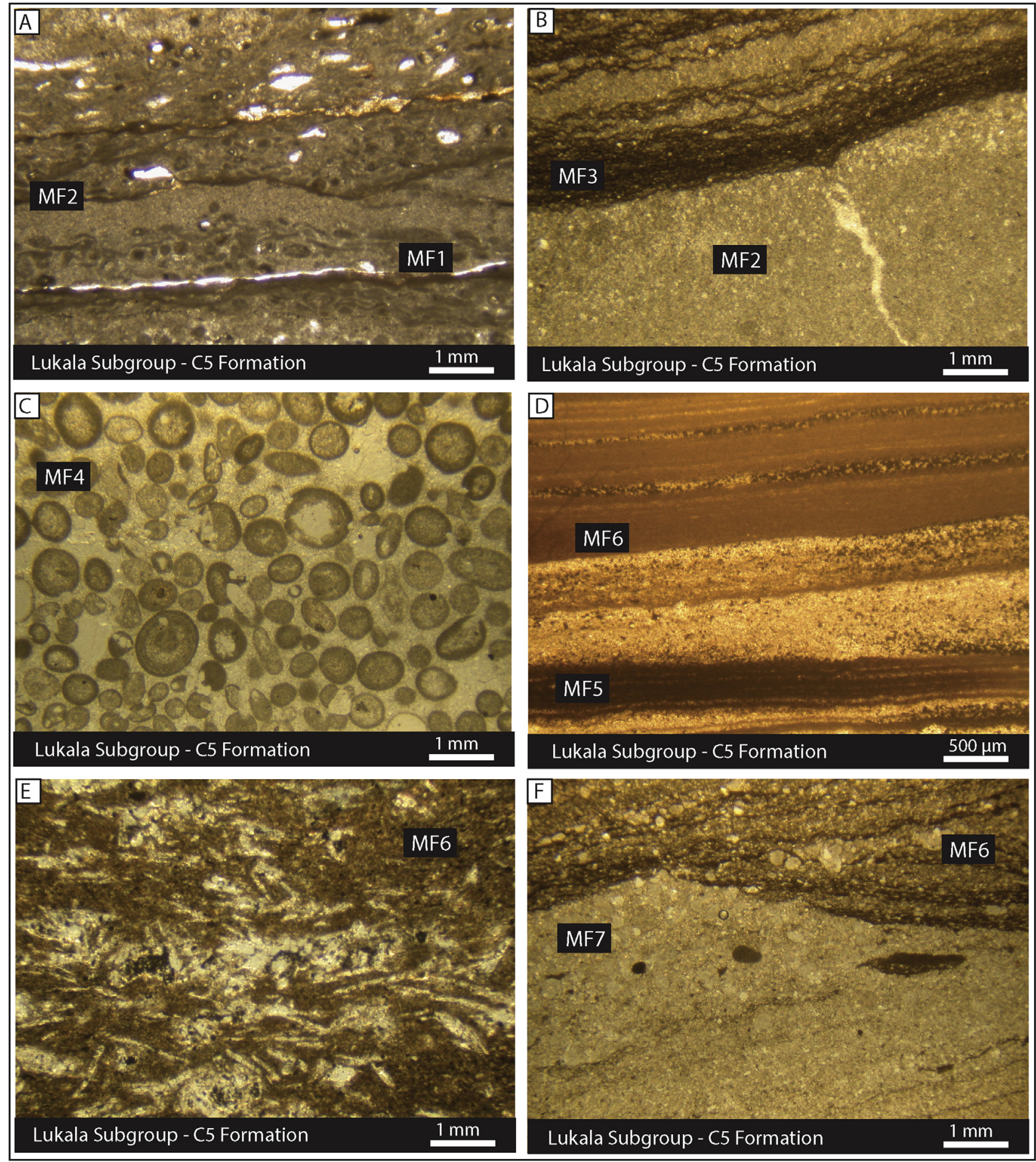

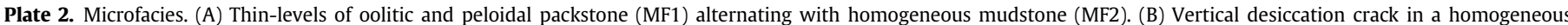

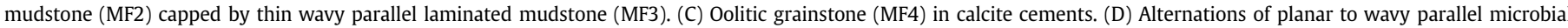

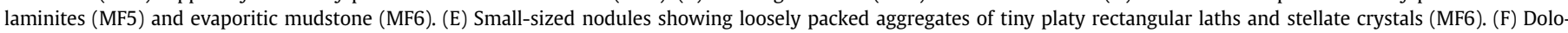
mitized lime mudstone (MF7) capped by evaporitic mudstone (MF6).

dolomicrosparite, in the dolomitized mudstones of the C5 Formation revealed that the sediments were flooded by mixed waters. $\mathrm{Sr}$ isotope ratios of these mudstones point to dolomitization shortly after deposition around $540 \mathrm{Ma}$.

Both our new $\delta^{13} \mathrm{C}$ values as well as previous data for the $\mathrm{C} 5$ Formation (Frimmel et al., 2006; Frimmel, 2010; Delpomdor and Préat, 2013), do not reflect alteration and thus provide a reliable tool for intrabasinal correlation. Numerous correlation attempts between the carbonate successions of the West Congo (Africa) and Bambuí (Brazil) have been performed (Alkmim and Martins-Neto, 2012; Caxito et al., 2012; Cailteux et al., 2015; Kuchenbecker et al., 2015) but are hampered by unequivocal radiometric dating of both successions (Santos et al., 2000, 2004; Vieira et al., 2007; Caxito et al., 2012; Guacaneme et al., 2017; Paula-Santos et al., 
2017).

The occurrence of the index fossil Obruchevella parva in the C5 Formation (Alvarez et al., 1995; in this study) is of little stratigraphic help as it indicates Tonian to early Ordovician ages (Reitlinger, 1959; Yakschin and Luchinina, 1981).

In the Bambuí Group, the $\delta^{13} \mathrm{C}$ isotopic fluctuations of the Sete Lagoas Formation (Fig. 10) mark changes from a shallow restricted setting dominated by freshwater input to a basin connected to external seawater intermittently devoid of efficient mixing of the waters (Paula-Santos et al., 2017). The occurrence of the index fossil Cloudina sp. in the uppermost Sete Lagoas Formation (Warren et al., 2014) correlated with Cloudina riemkeae from the Arroyo del Soldado Group in Uruguay (Gaucher, 2000), suggests a debatable Late Ediacaran age.

In the WCB, $\delta^{13} \mathrm{C}$ isotopic fluctuations are also known. A first example occurs between the upper part of the Haut-Shiloango and lower part of the Lukala subgroups (Fig. 10). It marks a rapid marine transgression as a result of extensional tectonic processes directly after the Marinoan period (Delpomdor et al., 2016). A second example, moreover also marked by abrupt lithological and chemical changes, corresponds to a marine transgression at the transition of the C3-C4 formations, which flooded the West Congo Basin of the WCB (Frimmel et al., 2006; Delpomdor and Préat, 2013; Cailteux et al., 2015; Préat et al., 2011, 2018). (Fig. 10). This transgression eventually gave rise to a restricted basin without an efficient mixing with external seawater. Because of the stagnant dysoxic to anoxic water columns the organic matter was preserved in the evaporitic shallower environments (C5 Formation). We suggest that the marine transgression at the transition of the $\mathrm{C} 3-\mathrm{C} 4$ formations favoured regional-scale interexchange with other basins accompanied by flora migration and development of Obruchevella parva in the C5 Formation of the WCB. In addition, the absence of the index fossil Cloudina sp. in the C5 Formation could be due to a later closure of the marine interconnection between the São Francisco and Congo Cratons. We argue that the marine transgression in the uppermost Sete Lagoas Formation (Brazil) and at the transition of the C3-C4 formations (WCB) were coeval and, therefore, allow to extend the debatable Late Ediacaran age of the uppermost Sete Lagoas Formation also to the C5 Formation.

In conclusion, various pathways of tentative dating of the $\mathrm{C5}$ Formation converge to a Late Ediacaran age with - more specifically - 575-550 Ma and 540 Ma.

In conclusion, the proposed ages for the C5 Formation are of interest in constraining the depositional age of the overlying Mpioka Subgroup, which represents the Pan African molasse of the WCB (Frimmel et al., 2006). As this molasse was folded, it suffered Pan African deformation, dated at $566 \pm 42 \mathrm{Ma}$ (Ar-Ar age for the regional metamorphism of the WCB; Frimmel et al., 2006). Unlike the previously generally accepted models, our data suggest that the molasse was deposited in the Early Cambrian.

\section{Conclusions}

New descriptions of key cores and outcrops in the Lower Congo section of the uppermost part of the Lukala Subgroup of the Democratic Republic of Congo show that the C5 carbonateevaporite ramp exhibits a vast shallow back-reef lagoon stretching between a stromatolitic patch reef barrier and a coastal sabkha plain. Sedimentological analysis displays warm and dry to semiarid climates, and seasonal flooding by meteoric waters. The carbonate-evaporite ramp succession is composed of peritidal cycles $\left(5^{\text {th }}\right.$-order elementary parasequences $)$ of approximately $2 \mathrm{~m}$ of thickness, that record a short-time marine regression, rapidly flooded by a marine transgression and deposition of organic-rich argillaceous carbonates or shales under dysoxia and anoxia conditions. These conditions were enhanced by a low subsidence rate in the lagoon center during the early stage of sea level highstand. Reducing conditions are inferred from the enrichments of Fe, Mn and trace metal elements, which were dissolved in solution by the scavenging of Fe-Mn-oxy-hydroxides and oxides and their accumulation in sulfides. The dysoxic/anoxic waters were replaced by well-oxygenated waters, with development of benthic Obruchevella parva-type 'seagrasses' in the nearshore zones of the lagoon. Our new $\delta^{13} \mathrm{C}$ and ${ }^{87} \mathrm{Sr} /{ }^{86} \mathrm{Sr}$ isotope data complete the dataset for the C5 Formation of the Lukala Subgroup and indicate a correlation with the Sete Lagoas succession in Brazil. Relatively comparable negative to positive $\delta^{13} \mathrm{C}$ excursions (from -7 to $+12 \%$ ) point to marine flooding of the whole basin, and, therefore, allows an extension of the debatable Late Ediacaran age for the uppermost Sete Lagoas Formation, to the C5 Formation. In our study, Sr isotope "blind dating" failed due to the low $\mathrm{Sr}$ concentration occurred by dolomitization close $540 \mathrm{Ma}$. The absence of the index fossil Cloudina sp. in the C5 Formation could be due to later closure of the marine interconnection between the São Francisco and Congo Cratons. The implication of the index fossil Obruchevella parva as Tonian to Cambro-Ordovician stratigraphic fossil can be debated, but the occurrence of this genus is closely related to the regionalscale marine transgression in the basin, favoring interexchange with other basins and flora migration. Various pathways of tentative dating of the C5 Formation converge to a Late Ediacaran age ranging between $575 \mathrm{Ma}$ and $540 \mathrm{Ma}$. Our data thus suggest that the overlying Mpioka Subgroup, which represents the Pan African molasse of the WCB, was deposited in the Early Cambrian.

\section{Acknowledgements}

The Royal Museum for Central Africa (Belgium) and the Center des Recherches Géologiques et Minières (Democratic Republic of Congo) are thanked for their agreement in publication of drill core logs and outcrop sections. The $\mathrm{C}$ and $\mathrm{O}$ isotope analyses were carried out at the University of Erlangen in Germany (Prof. Michael Joachimski). We acknowledge Scott Elrick (ISGS) for the helpful discussions and improving the English of the manuscript. We are grateful to Michel Villeneuve and anonymous reviewer for their careful edits that significantly improved the manuscript.

\section{References}

Adabi, M.H., Rao, C.P., 1996. Petrographic, elemental and isotopic criteria for the recognition of carbonate mineralogy and climates during the jurassic (examples from Iran and England) (Abstract). In: 13th Geological Convention. Australia, 6.

Adatte, T., Keller, G., Stüben, D., Harting, M., Kramar, U., Stinnesbeck, W., Abramovich, S., Bemjamini, C., 2005. Late Maastrichtian and K/T palaeoenvironment of the eastern Tethys (Israel): mineralogy, trace and platinum group elements, biostratigraphy and faunal turnovers. Bull. Société Géologique Fr. 176 (1) 37-55.

Affaton, P., Kalsbeek, F., Boudzoumou, F., Trompette, R., Thrane, K., Frei, R., 2016. The Pan-African west Congo belt in the republic of Congo (Congo brazzaville): stratigraphy of the mayombe and West Congo supergroups studied by detrital zircon geochronology. Precambrian Res. 272, 185-202.

Alkmim, F.F., Martins-Neto, M.A., 2012. Proterozoic first-order sedimentary sequences of the São Francisco craton, eastern Brazil. Mar. Petroleum Geol. 33, 127-139.

Alvarez, P., 1995. Les facteurs de contrôle de la sédimentation du Supergroupe Ouest-Congolien (Sud-Congo). Rampe Carbonatée et activité biologique au Protérozoïque Supérieur. Ed. BRGM 239, 286 p.

Alvarez, P., Maurin, J.-C., 1991. Evolution sédimentaire et tectonique du bassin protérozoïque supérieur de Comba (Congo): stratigraphie séquentielle du Supergroupe Ouest-Congolien et modèle d'amortissement sur décrochements dans le contexte de la tectogénèse panafricaine. Precambrian Res. 50,137-171.

Alvarez, P., Chauvel, J.-J., van Vliet-Lanoë, B., 1995. Obruchevella, cyanobactérie fossile du Protérozoïque supérieur du Congo. Implications sur l'âge du Groupe Schisto-Calcaire et de la glaciation fini-Protérozoïque. Compte Rendus de l'Académie des Sciences, Série 2. Sci. de Terre des Planètes 320 (7), 639-646.

Asmerom, Y., Jacobsen, S., Knoll, A.H., Butterfield, N.J., Swett, K., 1991. Strontium isotope variations of Neoproterozoic seawater: implications for crusta 
evolution. Geochimica Cosmochimica Acta 55, 2883-2894.

Babinski, M., Viera, L.C., Trindade, R.I.F., 2007. Direct dating of the Sete Lagoas cap carbonate (Bambuí Group, Brazil) and implications for the Neoproterozoic glacial events. Terra nova. 19 (6), 401-406.

Babinski, M., Paula-Santos, G.M., Kuchenbecker, M., Caetano-Filho, S., Trindade, R.I., Pedrosa-Soares, A.C., 2013. The Isotopic Record of the Bambui Group. Brazil: Sturtian, Marinoan, and/or Early Paleozoic? AGU Spring Meeting Abstracts, 2013.

Banner, J., Hanson, G., 1990. Calculation of simultaneous isotopic and trace element variations during water-rock interaction with applications to carbonate diagenesis. Geochimica Cosmochimica Acta 54, 3123-3137.

Baudet, D., Kant-Kabalu, F., Fernandez-Alonso, M., 2014. Carte géologique de la République du Congo, Province du Bas-Congo, avec notice explicative. Centre de Recherches Géologique et Minière (CRGM), Kinshasa, RDC et Musée royal de l'Afrique Centrale (MRAC), Tervuren, Belgique. ISBN 978-9-4916-1535-1.

Brand, U., Veizer, J., 1980. Chemical diagenesis of a multicomponent carbonate system-1: trace elements. J. Sediment. Petrology 50, 1219-1236.

Burchette, T.P., Wright, V.P., 1992. Carbonate ramp depositional systems. Geology 79, 3-57.

Cadwell, R.A., 1976. Holocene Gypsum Deposits of the Bullara Sunkland, Carnavaron Basin, Western Australia. PhD dissertation. University of Western Australia, Perth, $123 \mathrm{pp}$.

Cahen, L., 1954. Géologie du Congo belge. Imprimerie H. Vaillant-Carmanne, S.A., Liège, $577 \mathrm{pp}$.

Cahen, L., 1978. La stratigraphie et la tectonique du Supergroupe Ouest-Congolien dans les zones médiane et externe de l'orogenèse Ouest-Congolien (Pan-African) au Bas-Zaïre et dans les régions voisines. Annales du Musée royal de l'Afrique Centrale, Tervuren, in 8. Sci. Géologiques 83, 150 p.

Cahen, L., Lepersonne, J., 1976. Les mixtites du Bas-Zaïre: mise au point intérimaire. Musée royal de l'Afrique Centrale, Tervuren (Belgique), Département de Géologie et Minéralogie. Rapp. Annu. 33, 57 p.

Cailteux, J.L.H., Delpomdor, F.R.A., Ngoie Ndobami, J.-P., 2015. The Neoproterozoic West Congo "Schisto-Calcaire" sedimentary succession from the Bas-Congo region (Democratic Republic of the Congo) in the frame of regional tentative correlations. Geol. Belg. 18 (2-4), 126-146.

Canfield, D.E., Jørgensen, B.B., Fossing, H., Glud, R., Gundersen, J., Ramsing, N.B., Thamdrup, B., Hansen, J.W., Nielsen, L.P., Hall, P.O.J., 1993. Pathways of organic carbon oxidation in three continental margin sediments. Mar. Geol. 113, 27-40.

Caplan, M.L., Bustin, R.M., 1999. Devonian-Carboniferous Hangenberg mass extinction event, widespread organic-rich mudrock and anoxia: causes and consequences. Palaeogeogr. Palaeoclimatol. Palaeoecol. 148, 187-207.

Catuneanu, O., Galloway, W.E., Kendall, C.G.S.C., Miall, A.D., Posamentier, H.W., Strasser, A., Tucker, M.E., 2011. Sequence stratigraphy: methodology and nomenclature. Newsletters Stratigr. 44 (3), 173-245.

Caxito, F.A., Halverson, G.P., Uhlein, A., Stevenson, R., Dias, T.G., Uhlein, G.J., 2012. Marinoan glaciation in east central Brazil. Precambrian Res. 200-203, 38-58.

Delhaye, F., Sluys, M., 1920. Les grands traits de la tectonique du Congo occidental. Structure et stratigraphie du bassin schisto-calcareux (Note préliminaire). Annales de la Société Géologique de Belgique. Publ. Relat. au Congo. Belge. 43, C57-C74.

Delhaye, F., Sluys, M., 1923. Esquisse géologique du Congo occidentale. Etude du système Schisto-Calcaire, missions géologiques de 1914 et 1918-19. BruxellesUccle. Etablissement Cartographique E. Patesson, 1923-1924.

Delhaye, F., Sluys, M., 1924a. Observations ayant servi à l'élaboration de l'Esquisse géologique du Congo occidental. Etude du système schisto-calcaire (Echelle de $1 / 200.000$, Missions géologiques de 1914 et 1918-1919). Premier mémoire: La région plissée des abords du fleuve, entre Isangila et Manyanga. Annales de la Société Géologique de Belgique. Publ. Relat. au Congo. Belge. 47, C50-C148.

Delhaye, F., Sluys, M., 1924b. Observations ayant servi à l'élaboration de l'Esquisse géologique du Congo occidental. Etude du système schisto-calcaire (Echelle de 1/200.000, Missions géologiques de 1914 et 1918-1919). Deuxième mémoire: le massif de Kikenge et la région effondrée du bassin de la Luala. Annales de la Société Géologique de Belgique. Publ. Relat. au Congo. Belge. 47, C149-C191.

Delhaye, F., Sluys, M., 1929. Observations ayant servi à l'élaboration de l'Esquisse géologique du Congo occidental. Etude du système schisto-calcaire (Echelle de 1/200.000, Missions géologiques de 1914 et 1918-1919). Troisième mémoire: La région des plaines calcaires et les parties limitrophes au sud du fleuve dans la zone des plissements. Les observations faites le long de la ligne du chemin de fer. Le plateau schisto-gréseux des Cataractes-nord. Annales de la Société Géologique de Belgique. Publ. Relat. au Congo. Belge. 52, C69-C114.

Delpomdor, F., Préat, A., 2013. Early and Neoproterozoic C, O and Sr isotope chemostratigraphy in the carbonates of West Congo and Mbuji-Mayi supergroups: a preserved marine signature? Palaeogeogr. Palaeoclimatol. Palaeoecol. 389, $35-47$.

Delpomdor, F., Préat, A., 2015. Overview of the neoproterozoic sedimentary series exposed along margins of the Congo basin. In: de Wit, M., Guillocheau, F., de Wit, M.J. (Eds.), The Geology and Resource Potential of the Congo Basin. Springer-Verlag, pp. 41-58.

Delpomdor, F., Blanpied, C., Virgone, A., Préat, A., 2013. Paleoenvironments in meso-neoproterozoic carbonates of the mbuji-mayi supergroup (democratic republic of Congo)-Microfacies analysis combined with $\mathrm{C}-\mathrm{O}-\mathrm{Sr}$ isotopes, major-trace elements and REE+ Y distributions. J. Afr. Earth Sci. 88, 72-100.

Delpomdor, F., Kant, F., Préat, A., 2014. Neoproterozoic uppermost haut-shiloango subgroup (west Congo supergroup, democratic republic of Congo): misinterpreted stromatolites and implications for sea-level fluctuations before the onset of the marinoan glaciation. J. Afr. Earth Sci. 90, 49-63.

Delpomdor, F., Tack, L., Cailteux, J., Préat, A., 2015a. The C2 and C3 formations of the Schisto-Calcaire Subgroup (West Congo Supergroup) in the Democratic Republic of the Congo: an example of post-Marinoan sea-level fluctuations as a result of extensional tectonisms. J. Afr. Earth Sci. 110, 14-33.

Delpomdor, F., Virgone, A., Blanpied, C., Préat, A., 2015b. Sedimentology and sequence stratigraphy of late precambrian carbonates of the mbuji-mayi supergroup in the sankuru-mbuji-mayi-lomami-lovoy basin (democratic republic of the Congo). In: de Wit, M., Guillocheau, F., de Wit, M.J. (Eds.), Geology and Resource Potential of the Congo Basin, Regional Geology Reviews. SpringerVerlag, pp. 59-76.

Delpomdor, F., Eyles, N., Tack, L., Préat, A., 2016. Pre- and post-Marinoan carbonate facies of the Democratic Republic of the Congo: glacially- or tectonicallyinfluenced deep-water sediments? Palaeogeography, Palaeoclimatology. Palaeoecology 457, 144-157.

Delpomdor, F.R.A., Tack, L., Préat, A.R., 2017. Facies and micromorphology of the neoproterozoic upper Diamictite Formation in the democratic republic of Congo: new evidence of sediment gravity flow. Geol. Belg. 20 (1-2), 69-79.

De Paepe, P., Hertogen, J., Tack, L., 1975. Mise en évidence de laves en coussin dans les faciès volcaniques basiques du massif de Kibungu (Bas-Zaïre) et implications pour le magmatisme ouest-congolien. Ann. Société Géologique Belg. 98, 251-270.

Derry, L.A., Kaufman, A.J., Jacobsen, S.B., 1992. Sedimentary cycling and environmental change in the Late Proterozoic: evidence from stable and radiogenic isotopes. Geochimica Cosmochimica Acta 56, 1317-1329.

Derry, L.A., Brasier, M.D., Corfield, R.M., Rozanov, A.Y., Zhuravlev, A.Y., 1994. Sr and C isotopes in Lower Cambrian carbonates from the Siberian craton: a paleoenvironmental record during the "Cambrian explosion". Earth Planet. Sci. Lett. $128,671-681$.

Derry, L.A., Keto, L.S., Jacobsen, S.B., Knoll, A.H., Swet, K., 1989. Sr isotopic variations in upper proterozoic carbonates from svalbard and east Greenland. Geochimica Cosmochimica Acta 53, 2331-2339.

Dunham, R.J., 1962. Classification of carbonate rocks according to depositional texture. In: Ham, W.E. (Ed.), Classification of Carbonate Rocks, vol. 1. American Association of Petroleum Geologists Memoir, pp. 108-121.

Embry, A.F., Klovan, J.E., 1972. Absolute water depth limits of late Devonian paleoecological zones. Geol. Rundsch 61, 672-686.

Eyles, N., Januszczak, N., 2007. Syntectonic subaqueous mass flows of the Neoproterozoic Otavi Group, Namibia: where is the evidence of global glaciation? Basin Res. 19, 179-198.

Franseen, E.K., Byrnes, A.P., 2012. Arkuckle group platform strata in Kansas: a synthesis. In: Derby, J.R., Fritz, R.D., Longacre, S.A., Morgan, W.A., Sternbach, C.A. (Eds.), The Great American Carbonate Bank: the Geology and Economic Resources of the Cambrian-ordovician Sauk Megasequence of Laurentia, vol. 98. AAPG Memoir, pp. 1031-1047.

Frimmel, H.E., 2009. Trace element distribution in Neoproterozoic carbonates as palaeoenvironmental indicator. Chem. Geol. 258 (3-4), 338-353.

Frimmel, H.E., 2010. On the reliability of stable carbon isotopes for Neoproterzoic chemostratigraphic correlation. Precambrian Res. 182 (4), 239-253.

Frimmel, H.E., Tack, L., Basei, M.S., Nutman, A.P., Boven, A., 2006. Provenance and chemostratigraphy of the neoproterozoic West Congolian group in the democratic republic of Congo. J. Afr. Earth Sci. 46, 221-239.

Gaucher, C., 2000. Sedimentology, paleontology and stratigraphy of the Arroyo del Soldado Group (Vendian to Cambrian; Uruguay). Beringeria 26, 1-120.

Grotzinger, J.P., 1986. Cyclicity and paleoenvironmental dynamics, Rocknest platform, northwestern Canada. Geol. Soc. Am. Bull. 97, 1208-1231.

Guacaneme, C., Babinski, M., Paula-Santos, G.M., Perdrosa-Soares, A.C., 2017. C, O, and $\mathrm{Sr}$ isotopic variations in neoproterozoic-cambrian carbonate rocks from Sete Lagoas Formation (Bambuí group), in the southern São Francisco basin, Brazil. Braz. J. Geol. 47 (3), 521-543. https://doi.org/10.1590/23174889201720160126.

Halverson, G.P., Hoffman, P.F., Schrag, D.P., Maloof, A.C., Rice, A.H.N., 2005. Towards a Neoproterozoic composite carbon isotope record. Geol. Soc. Am. Bull. 117, 1181-1207.

Halverson, G.P., Dudas, F.O., Maloof, A.C., Bowring, S.A., 2007. Evolution of the ${ }^{87} \mathrm{Sr} /{ }^{86} \mathrm{Sr}$ composition of neoproterozoic seawater. Palaeogeography, palaeoclimatology. Palaeoecology 256, 103-129.

Halverson, G.P., Wade, B.P., Hurtgen, M.T., Barovich, K.M., 2010. Neoproterozoic chemostratigraphy. Precambrian Res. 182 (4), 337-350.

Hoffman, P.F., Schrag, D.P., 2002. The snowball Earth hypothesis: testing the limits of global change. Terra nova. 14, 129-155.

Hood, A.V.S., Wallace, M.W., 2015. Extreme ocean anoxia during the Late Cryogenian recorded in reefal carbonates of Southern Australia. Precambrian Res. 261, 96-111.

Jacobsen, S.B., Kaufman, A.J., 1999. The Sr, C and O isotopic evolution of Neoproterozoic seawater. Chem. Geol. 161, 37-57.

Kampunzu, A.B., Kapenda, D., Manteka, B., 1991. Basic magmatism and geotectonic evolution of the Pan African belt in Central Africa: evidence from the Katangan and West Congolian segments. Tectonophysics 190, 363-371.

Kant-Kabalu, F., Kadja-Wongudi, G., Mujinga-Mulemba, E., Nseka-Mbemba, P., Phambu-Landu, J., Kanda-Nkula, V., Baudet, D., Dewaele, S., Eekelers, K., DFernandez, M., Laghmouch, M., Theunissen, K., Tack, L., 2016. New 1/500.000 scale GIS-based geological and mineral resources maps for Bas-Congo province (DRC) with an updated lithostratigraphy of the Neoproterozoic West Congo Supergroup. In: 5th International Geologica Belgica 2016 Congress, 26-29 
January 2016. University of Mons, Mons, Belgium, pp. 42-43. Abstract Book.

Kaufman, A.J., Jacobsen, S.B., Knoll, A.H., 1993. The Vendian record of Sr and C isotopic variations in seawater: implications for tectonics and paleoclimate. Earth Planet. Sci. Lett. 120, 409-430.

Kaufman, A.J., Sial, A.N., Frimmel, H.E., Misi, A., 2010. Neoproterozoic to cambrian paleoclimatic events in soutwestern gondwana. In: Gaucher, C., Sial, A.N. Halverson, G.P., Frimmel, H.E. (Eds.), Neoproterozoic-cambrian Tectonics, Global Change and Evolution: a Focus on Southwestern Gondwana. Developments in Precambrian Geology, vol. 16. Elsevier, pp. 369-388.

Kinsman, D.J.J., 1969. Modes of formation, sedimentary associations and diagnostic features of shallow-water and supratidal evaporates. Am. Assoc. Petroleum Geol. Bull. 53, 830-840.

Kirschvink, J.L., 1992. Late proterozoic low-latitude global glaciation: the snowball earth. In: Schopf, J.W., Klein, C. (Eds.), The Proterozoic Biosphere: a Multidisciplinary Study. Cambridge University Press, pp. 51-52.

Kuchenbecker, M., Pedrosa-Soares, A.C., Babinski, M., Fanning, M., 2015. Detrita zircon age patterns and provenance assessment for pre-glacial to post-glacial successions of the Neoproterozoic Macaúbas Group, Araçuaí orogen. Braz. Precambrian Res. 266, 12-26.

Land, L.S., 1980. The isotopic and trace element geochemistry of dolomite: the state of the art. In: Zenger, D.H., Dunham, J.B., Ethington, R.L. (Eds.), Concepts and Models of Dolomitization, vol. 28. Society for Sedimentary Geology, Special Publications, pp. 87-110.

Logan, B.W., Rezak, R., Ginsburg, R.N., 1964. Classification and environmental significance of algal stromatolites. J. Geol. 72, 68-83.

Lepersonne, J., 1974. Carte géologique à l'échelle 1/200000. Notice explicative de la feuille Ngungu (Degré carré S6/14 = SB 33.9). République Démocratique du Congo. Département des Mines, Direction du Service Géologique, 61 p.

Meyer, E.E., Quicksall, A.N., Landis, J.D., Link, P.K., Bostick, B.C., 2012. Trace and rare earth elemental investigation of a Sturtian cap carbonate, Pocatello, Idaho: evidence for ocean redox conditions before and during carbonate deposition. Precambrian Res. 192-195, 89-106.

Miall, A.D., 1997. The Geology of Stratigraphic Sequences. Springer-Verlag, Berlin, 433 pp.

Mickala, O.-R., Vidal, L., Boudzoumou, F., Affaton, P., Vandamme, D., Borschnec, D., Mounguengui, M.M., Fournier, F., Malouguila Nganga, D.M., Miche, H., 2014 Geochemical characterization of the marinoan "cap carbonate" of the niarinyanga basin (Central Africa). Precambrian Res. 255 (1), 367-380.

Muanza-Kant, P., Mpiana, Ch, Kanda-Nkula, V., Tack, L., Baudet, D., Archibald, D.B. Glorie, S., 2016. The lower Diamictite Formation of the Cataractes group, west Congo supergroup (Bas-Congo, DRC): a 700 Ma marker of extensional episodic activity during breakup of columbia. In: 5th International Geologica Belgica 2016 Congress, 26-29 January 2016. University of Mons, Mons, Belgium, p. 57. Abstract Book.

Paula-Santos, G.M., Caetano-Filho, S., Babinski, M., Trindade, R.I.F., Guacaneme, C., 2017. Tracking connection and restriction of west gondwana São Francisco basin through isotope chemostratigraphy. Gondwana Res. 42, 280-305.

Pedrosa-Soares, A.C., Alkmin, 2011. How many rifting events preceded the development of the Araçuai-West Congo orogen? Geonomos 19 (2), 244-251.

Pedrosa-Soares, A.C., Babinski, M., Noce, C., Martins, M.S., Queiroga, G., Vilela, F. 2011. The Neoproterozoic Macaúbas Group (Araçuá orogen, SE Brazil) with emphasis on the diamictite formations. In: Arnaud, E., Halverson, G., Shields, G. (Eds.), The Geological Record of Neoproterozoic Glaciations, vol. 36. Geological Society of London, Memoir, pp. 523-534.

Pedrosa-Soares, A.C., Alkmin, F., Tack, L., Noce, C., Babinski, M., Silva, L., MartinsNeto, M., 2008. Similarities and differences between the brazilian and african counterparts of the neoproterozoic Araçuaí-West Congo orogen. In: Pankhurst, J., Trouw, R., Brito-Neves, B., De Wit, M. (Eds.), West Gondwana: Precenozoic Correlations across the South Atlantic Region, vol. 294. Geological Society, London, Special Publications, pp. 153-172.

Piper, D.Z., 1971. The distribution of Co, 0, Cu, Fe, Mn, Ni and $\mathrm{Zn}$ in Framvarcn, a Norwegian anoxic fjord. Geochimica Cosmochimica Acta 35, 531-550.

Poidevin, J.-L., 2007. Stratigraphie isotopique du strontium et datation des formations carbonatées et glaciogéniques néoprotérozoïques du Nord et de l'Ouest du craton du Congo. Comptes Rendus Geosci. 339, 259-273.

Posamentier, H.W., Allen, G.P., 1999. Siliciclastic sequence stratigraphy: concepts and applications. Society and Economist Paleontolongists and Mineralogists. Concepts Sedimentology Paleontology 7, 210.

Pratt, B.R., James, N.P., Clinton, A.C., 1992. Peritidal carbonates, In: Walker, R.G James, N.P. (Eds.), Facies Models: Response to Sea Level Change. Geological Association of Canada, p. 409.

Préat, A., Prian, J.P., Thiéblemont, D., Mabicka Obame, R., Delpomdor, F., 2011. Stable isotopes of oxygen and carbon compositions in the Neoproterozoic of South Gabon (Schisto-Calcaire Subgroup, Nyanga Basin): are cap carbonates and lithoherms recording a particular destabilization event after the Marinoan glaciation? J. Afr. Earth Sci. 60 (4), 273-287.
Préat, A., Kolo, K., Prian, J.-.P., Delpomdor, F., 2010. A peritidal evaporate environment in the neoproterozoic of south Gabon (Schisto-Calcaire subgroup, nyanga basin). Precambrian Res. 177 (3-4), 253-265.

Préat, A., Delpomdor, F., Ackouala Mfere, A.P., Callec, Y., 2018. Paleoenvironments, $\delta^{13} \mathrm{C}$ and $\delta^{18} \mathrm{O}$ signatures in the neoproterozoic carbonates of the comba basin, republic of Congo: implications for regional correlations and marinoan event. J. Afr. Earth Sci. 137, 69-90.

Raiswell, R., Canfield, D.E., 1998. Sources of iron for pyrite formation in marine sediments. Am. J. Sci. 298, 219-245.

Reitlinger, E.A., 1959. Atlas des restes microscopiques et des Problemática des couches anciennes de Sibérie. Travaux de Géologie. Atlas Nauka Acad. Sci. URSS $25,1-63$.

Rodrigues, J.B., 2008. Proveniência dos sedimentos dos grupos Canastra, Ibia, Vazante e Bambuí. Um estudo de zircões detriticos e idades modelo Sm-Nd. PhD thesis. Instituto de Geociências da Universidade de Brasília, Brasília, 129 p.

Santos, R.V., S. de Alvarenga, C.J., Dardenne, M.A., Sial, A.N., Ferreira, V.P., 2000 Carbon and oxygen isotope profiles across Meso-Neoproterozoic limestones from central Brazil: bambuí and Paranoá groups. Precambrian Res. 104, $107-122$.

Santos, R.V., Souza de Alvarenga, C.J., Babinski, M., Ramos, M.L.S., Cukrov, N., Fonseca, M.A., Sial, A.N., Dardenne, M.A., Noce, C.M., 2004. Carbon isotopes of mesoproterozoic sequences from southern São Francisco craton and Araçuaí belt, Brazil: paleographic implications. J. S. Am. Earth Sci. 18, 27-39.

Schröder, S., Grotzinger, J.P., 2007. Evidence for anoxia at the Ediacaran-Cambrian boundary: the record of redox-sensitive trace elements and rare-earth elements in Oman. J. Geol. Soc. Lond. 164, 175-187.

Scoffin, T.P., Stoddard, D.R., 1983. Beachrock and intertidal cements. In: Goudie, A.S., Pye, K. (Eds.), Chemical Sediments and Geomorphology. Academic Press, London, pp. 401-425.

Shearman, D.J., 1978. Evaporites of coastal sabkhas. Society and economist paleontolongists and mineralogists. Short. Course 4, 6-42.

Straathof, G.B., 2011. Neoproterozoic Low Latitude Glaciations: an African Perspective. Ph.D. Thesis. University of Edinburgh, 283 pp., unpublished.

Tack, L. Wingate, M.T.D, Liégeois, J.-P, Fernandez-Alonzo, M., Deblond, A, 2001 Early neoproterozoic magmatism (1000-910 Ma) of the zadinian and mayumbian groups (Bas-Congo), onset of rodinia rifting at the western edge of the Congo craton. Precambrian Res. 110, 277-306.

Tack, L., Fernandez-Alonso, M., Kanda Nkula, V., Mpoyi, J., Delvaux, D., Trefois, Ph, Baudet, D., 2006. Neoproterozoic diamictites around the Congo River Basin: a critical reappraisal of their origin. In: 21th Colloquium African Geology (CAG21), Maputo (Mozambique), 03-05.07.2006, Abstract Book, pp. 152-154.

Tack, L., Theunissen, K., Delvaux, D., Everaerts, M., Fernandez-Alonso, M., Baudet, D., 2016. The West Congo Belt of Bas-Congo (DRC) revisited: a patchwork of individual tectono-metamorphic domains as a result of South Atlantic Ocean opening. In: 5th International Geologica Belgica 2016 Congress, 26-29 January 2016. University of Mons, Mons, Belgium, p. 58. Abstract Book.

Thiéblemont, D., Castaing, C., Billa, M., Bouton, A., Préat, A., 2009. Notice explicative de la carte géologique et des ressources minérales de la République Gabonaise à 1/1000000. Programme Sysmin 8 ACP GA 017, Ministère des Mines, du Pétrole, des Hydrocarbures. Dir. Générale des Mines de Géologie, 384 pp.

Tribovillard, N., Algeo, T.J., Lyons, T.W., Riboulleau, A., 2006. Trace metals as paleoredox and paleoproductivity proxies: an update. Chem. Geol. 232, 12-32.

Tucker, M.E., 1991. Sequence stratigraphy of carbonate-evaporite basins; models and application to the upper permian (zechstein) of northeast England and adjoining north sea. J. Geol. Soc. Lond. 148, 1019-1036.

Tucker, M.E., Wright, V.P., 1990. Carbonate Sedimentology. Blackwell, Oxford, 482 p.

Van Wagoner, J.C., 1995. Sequence stratigraphy and marine to non-marine facies architecture of foreland basin strata, Book Cliffs, Utah, USA. In: Van Wagoner, J.C., Bertram, G.T. (Eds.), Sequence Stratigraphy of Foreland Basin Deposits - Outcrop and Subsurface Examples from the Cretaceous of North America, vol. 64. American Association of Petroleum Geologists Memoir, pp. 137-223.

Veizer, J., Compston, W., Clauer, N., Schidlowski, M., 1983. ${ }^{87} \mathrm{Sr} /{ }^{86} \mathrm{Sr}$ in Late Proterozoic carbonates: evidence for a 'mantle' event at 900 Ma ago. Geochimica Cosmochimica Acta 47, 295-302.

Vieira, L.C., Almeida, R.P., Trindade, R.I.F., Nogueira, A.C.R., Janikian, L., 2007. A Formação Sete Lagoas em sua área tipo: fácies, estratigrafia e sistemas deposicionais. Rev. Bras. Geociências 37 (4), 1-14.

Wachter, E., Hayes, J.M., 1985. Exchange of oxygen isotopes in carbon-dioxide phosphoric acid systems. Chem. Geol. 52, 365-374.

Warren, L.V., Quaglio, F., Riccomini, C., Simoes, M.G., Poiré, D.G., Strikis, N.M., Anelli, A., Strikis, P.C., 2014. The puzzle assembled: Ediacaran guide fossil Claudina reveals an old proto-Gondwana seaway. Geology 42 (5), 391-394.

Yakschin, M.S., Luchinina, V.A., 1981. New materials of fossil alga family oscillatoriaceae (KIRCHN.) elenkin. In: Boundary Strata between the Precambrian and Cambrian in Siberian Platform, pp. 28-34. Novosibirsk, Sci. 